\title{
Borehole Stability in \\ Densely Welded Tuffs
}

TI92 018776

Manuscript Completed: September 1991

Date Published: July 1992

Prepared by

K. Fuenkajorn, J. J. K. Daemen

Department of Mining and Geological Engineering

University of Arizona

Tucson, AZ 85721

Prepared for

Division of Regulatory Applications

Office of Nuclear Regulatory Research

U.S. Nuclear Regulatory Commission

Washington, DC 20555

NRC FIN L1476 


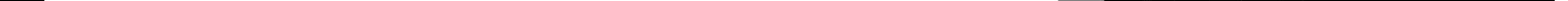




\section{DISCLAIMER}

Portions of this document may be illegible in electronic image products. Images are produced from the best available original document. 
Failure of the host rock at locations where seals are installed may allow the development of bypass flowpaths around seals. This report presents an investigation of conditions that might induce compressive failure around boreholes in densely welded Apache Leap tuff. Triaxial and polyaxial tests have been performed on tuff cylinders and rectangular blocks containing coaxial cored holes. Nominal test hole diameters are $14 \mathrm{~mm}$ for triaxial testing and $25.4 \mathrm{~mm}$ for biaxial testing.

To induce borehole breakout failures requires the application of stresses that exceed significantly the stresses corresponding to elastically calculated boundary stresses equal to the uniaxial compressive strength of the tuff. The results confirm the strength increase of welded tuff with density. Failure patterns are influenced by the heterogeneity of the rock: soft inclusions fail first. Such failures tend to remain localized. The stronger surrounding matrix provides the strength needed to maintain hole stability. The results suggest that an elastic analysis of hole stability in welded tuff may inherently provide a significant safety margin. This conclusion needs to be qualified by the fact that all experiments reported on have been conducted on boreholes with very small diameters.

It would be desirable to conduct similar borehole stability experiments on holes with larger diameters. Of particular importance would be an evaluation of the influence of flow layers in tuff on borehole stability. Effects of flow layers have been minimized in the present investigation by preparing all samples normal to the flow layers. Also desirable would be an investigation of the influence of environmental conditions, especially temperature and moisture content, and of the strength under sustained long-term loading. Finally, a more comprehensive analysis of the results should be performed, including evaluation of the numerous more recently published theoretical models for borehole breakouts. 
TABLE OF CONTENTS

Page

ABSTRACT

iii

LIST OF FIGURES

vii

LIST OF TABLES

viii

ACKNOWLEDGEMENTS . . . . . . . . . . . . . . . . . . . IX

LIST OF SYMBOLS . . . . . . . . . . . . . . . . . . . . . . xi

EXECUTIVE SUMMARY . . . . . . . . . . . . . . . . . . 1

CHAPTER ONE: INTRODUCTION .................. . 3

1.1 Objective..................... 3

1.2 Scope and Limitations . . . . . . . . . . . . . . . 3

1.3 Organization ................ . . 3

1.4 Borehole Instability or Borehole Breakouts - Background 4

1.5 Source Locations and General Description of Tuff

Samples . . . . . . . . . . . . . . . 9

CHAPTER TWO: BOREHOLE STABILITY TESTING . . . . . . . . . . . . 10

2.1 Introduction .................. 10

2.2 Triaxial Borehole Stability Testing . . . . . . . . . . 10

2.2.1 Test Method and Sample Preparation . . . . . . . 10

2.2.2 Test Method and Sample Preparation. . . . . . . 10

2.2.2.1 Sample AP22-3-2-BS1 . . . . . . . . 10

2.2.2.2 Sample AP22-4-2-BS1 . . . . . . . . 10

2.2.3 Discussion . . . . . . . . . . . . . . . 10

$\begin{array}{lll}2.3 & \text { Biaxial Borehole Stability Testing - Using Polyaxial } & \\ & \text { Cell . . . . . . . . . . . . . . . . . . . } 20\end{array}$

2.3.1 Test Method and Sample Preparation . . . . . 20

2.3.2 Test Results . . . . . . . . . . . . . . 20

2.3.3 Discussion . . . . . . . . . ...... 20

2.4 Biaxial Borehole Stability Testing - Using the Lateral

Load Frame . . . . . . . . . . . . . . . . . . . . 27

2.4.1 Test Method and Sample Preparation. . . . . . . 27

2.4.2 Test Method and Sample Preparation . . . . . . . 27

2.4.2.1 Sample AP60-1-BX2 . . . . . . . . 27

2.4.2.2 Sample AP61-1-BX3 ......... 30

2.4.2.3 Sample AP70-1-BS4 . . . . . . . . . 30

2.4.2.4 Sample AP71-1-BS7 . . . . . . . . 32

2.4.2.5 Sample AP70-2-BS5 . . . . . . . . . 32

2.4.2.6 Sample AP61-2-BS8 . . . . . . . . . 32

2.4.2.7 Sample AP61-3-BS9 . . . . . . . . . 33

2.4.3 Discussion . . . . . . . . . . . . . . . . . . 33

2.5 Strength of Boreholes in Apache Leap Tuff . . . . . . . 35 
TABLE OF CONTENTS - - Continued

Page

CHAPTER THREE: CONCLUSIONS AND RECOMMENDATIONS FOR FUTURE RESEARCH

3.1 Conclusions

3.2 Recommendations for Future Research . . . . . . . . . 38

REFERENCES

APPENDIX A: PROCEDURE FOR TRIAXIAL BOREHOLE DEFORMATION AND STABILITY TESTS

APPENDIX B: INSTALIATION PROCEDURE FOR STRAIN GAGE INSIDE

A BOREHOLE . . . . . . . . . . . . . . . . . . 51

APPENDIX C: PROCEDURE FOR BIAXIAL BOREHOLE DEFORMATION AND STABILITY TESTS USING POLYAXIAL CELL . . . . . . . . 47

APPENDIX D: PROCEDURE FOR BIAXIAL BOREHOLE STABILITY TESTS USING LATERAL LOAD FRAME 


\section{LIST OF FIGURES}

Eigure

Page

1.1 Borehole breakout orientation . . . . . . . . . . . 5

2.1 Dimensions of sample AP22-3-2-BS1, prepared from Apache Leap tuff for triaxial borehole stability test . . . . . . . .

2.2 Dimensions of sample AP22-4-2-BS2, prepared from Apache Leap tuff for triaxial borehole stability test . . . . . . . . .

2.3 Isotropic and plane strain solutions plotted with axial strain test data and linear best fit for sample AP22-3-2-BS1, as a function of lateral stress .......

2.4 Isotropic and plane strain solutions plotted with lateral strain test data and linear best fit for sample AP22-3-2-BS1, as a function of lateral stress . . . . . .

2.5 Isotropic and plane strain solutions plotted with axial strain test data and linear best fit for sample AP22-4-2-BS2, as a function of lateral stress ......

2.6 Isotropic and plane strain solutions plotted with lateral strain test data and linear best fit for sample AP22-4-2-BS2, as a function of lateral stress . . . . . .

2.7 Dimensions of sample TPS-PX1, prepared from Topopah Spring tuff for polyaxial borehole stability test. . . . . . . .

2.8 Orientation and location of strain gages $1,2,3$ and 4 with respect to loading direction ..............

2.9 Results of sample TPS-PXI, $\sigma_{y}=0, \sigma_{x}$ increases from 0 to $20 \mathrm{MPa}$. . . . . . . . . . . . . . . . . .

2.10 Results of sample TPS-PX1, $\sigma_{y}=0, \sigma_{y}$ increases from 0 to $20 \mathrm{MPa}$. . . . . . . . . . . . . . . . . . . 25

2.11 Uniform lateral stress . . . . . . . . . . . . 26

2.12 Dimensions of biaxial borehole stability test samples . . . 28

2.13 Applied stresses as a function of time for sample P60-1-BX2 29

2.14 Applied vertical and horizontal stresses as a function of time for sample AP61-1-BX3 . . . . . . . . . . . . . .

2.15 Tangential compressive stress at breakouts as a function of sample density . . . . . . . . . . . . . . . . . . 


\section{LIST OF TABLES}

Table

Page

2.1 Triaxial Test Results: Sample AP-22-3-2-BS1 . . . . . . . 13

2.2 Triaxial Borehole Stability Test Results:

Sample AP-22-4-2-BS2 . . . . . . . . . . . . . . 17

2.3 Results of Biaxial Borehole Deformation and Stability

Tests: Sample TPS-PX1 (Topopah Spring Tuff) . . . . . . . 22 


\section{ACKNOWLEDGEMENTS}

The research reported on has been performed by the University of Arizona, Department of Mining and Geological Engineering, for the U.S. Nuclear Regulatory Commission (NRC). Project monitor for the NRC is Mr. Jacob Philip. The project is under Mr. M. Silberberg, Chief, Waste Management Branch, Division of Engineering, Office of Nuclear Regulatory Research.

Dr. Jaak J.K. Daemen, Adjunct Associate Professor, Department of Mining and Geological Engineering, University of Arizona, is the Principal Investigator. Dr. James G. McCray, Acting Director, Nuclear Fuel Cycle Research Program, Department of Nuclear and Energy Engineering, University of Arizona, has provided project management assistance and nuclear waste technical assistance. Dr. Kittitep Fuenkajorn has performed the theoretical and experimental work. Experimental assistance has been provided by Robert Armstrong, David Young, and David Smith. Mike Porter has typed, assembled, and produced the report.

We gratefully acknowledge the permission of Mr. Frank Florez of Magma Copper Co., Superior, Arizona, for allowing us to collect rock samples for testing purposes. 


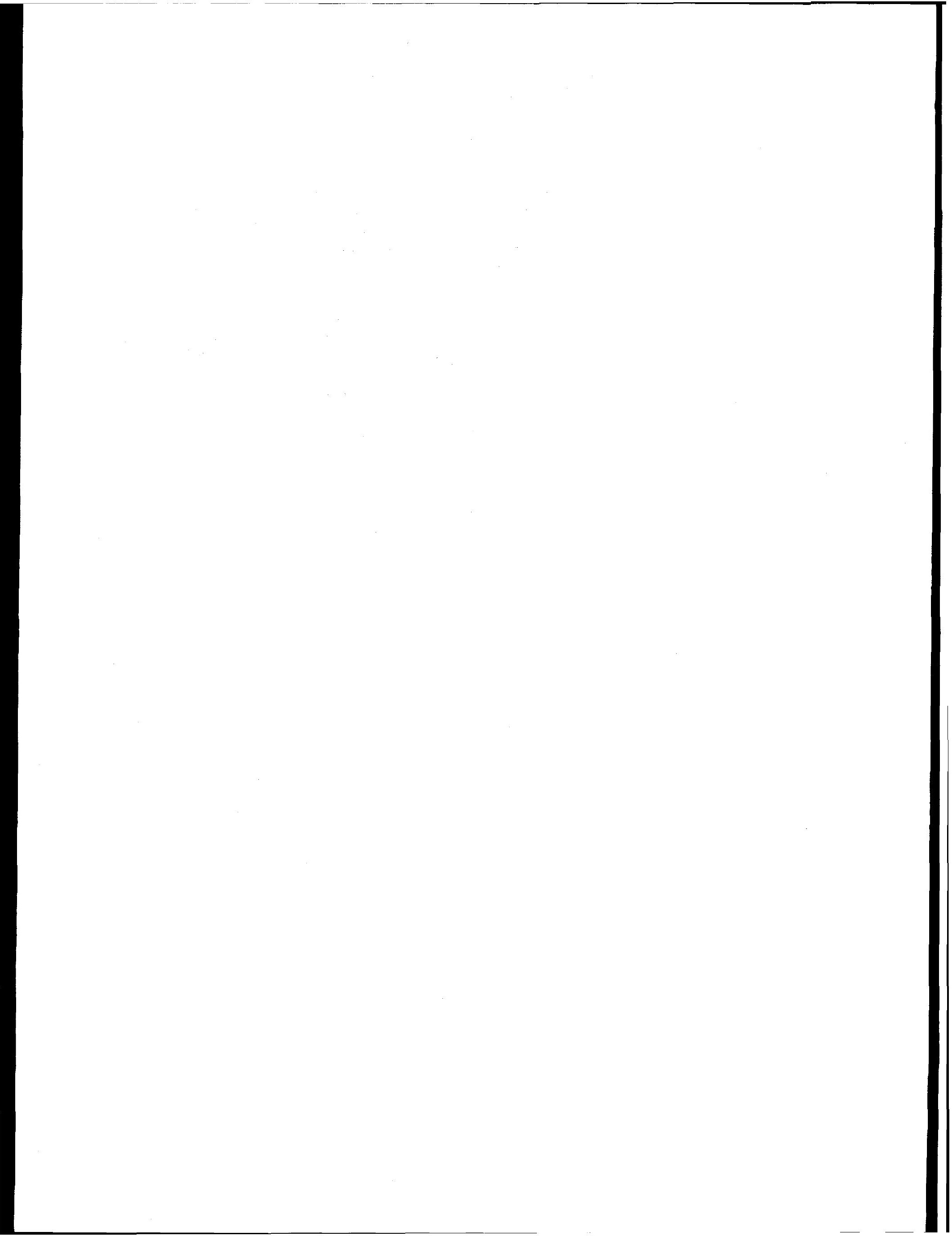




\section{LIST OF SYMBOLS}

Roman Symbols

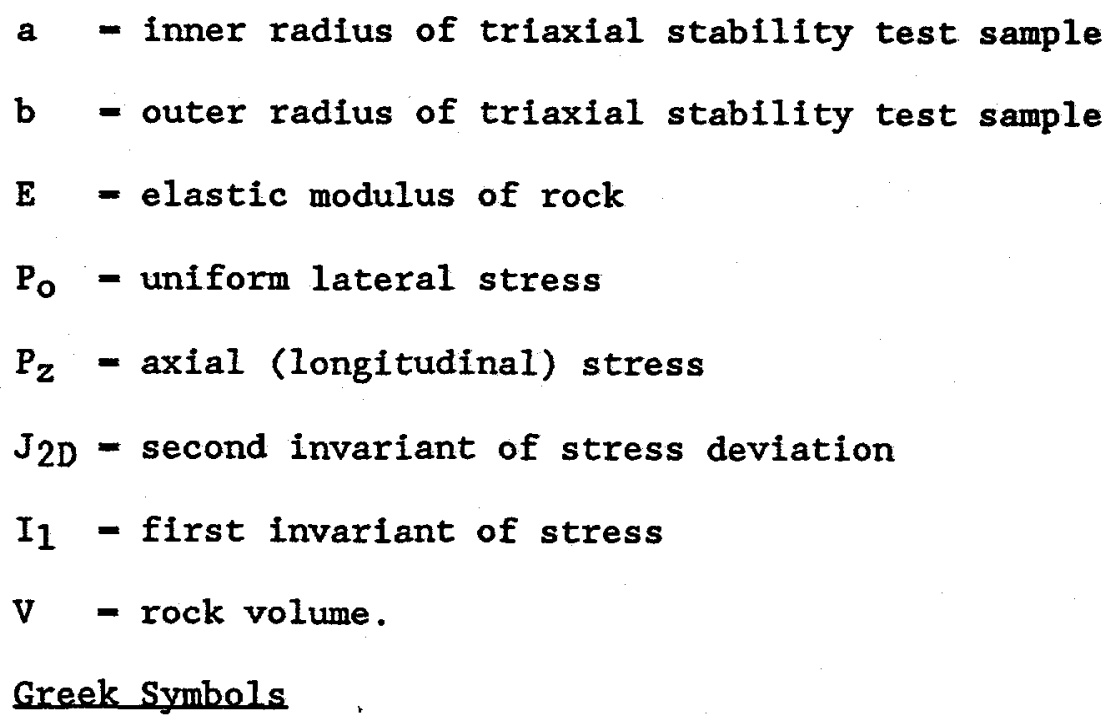


The stability of boreholes, or more generally of underground openings (i.e. including shafts, ramps, drifts, tunnels, etc.) at locations where seals or plugs are to be placed is an important consideration in seal design for a repository (Juhlin and Sandstedt, 1989). Borehole instability or borehole breakouts induced by stress redistribution could negate the effectiveness of seals or plugs. Breakout fractures along the wall of repository excavations or exploratory holes could provide a preferential flowpath for groundwater or gaseous radionuclides to bypass the plugs. After plug installation, swelling pressures exerted by a plug could induce radial cracks or could open or widen pre-existing cracks in the rock at the bottom of the breakouts where the tangential compressive stresses have been released by the breakout process.

The purpose of the work reported here is to determine experimentally the stability of a circular hole in a welded tuff sample subjected to various external boundary loads. Triaxial and biaxial borehole stability tests have been performed on densely welded Apache Leap tuff samples and Topopah Spring tuff samples. The nominal diameter of the test hole is 13.3 or $14.4 \mathrm{~mm}$ for triaxial testing, and $25.4 \mathrm{~mm}$ for biaxial testing. The borehole axis is parallel to one of the principal stress axes. The boreholes are drilled through the samples prior to applying external boundary loads. The boundary loads are progressively increased until breakouts occur or until the maximum load capacity of the loading system has been reached.

In triaxial borehole stability testing, no borehole breakout has been observed when the Apache Leap tuff samples are subjected to uniform lateral and axial stresses up to $42 \mathrm{MPa}$. The boreholes tend to deform linearly with increasing applied stresses. Small permanent deformations (strains) are observed after unloading.

Three loading series of biaxial borehole stability tests have been performed on a Topopah Spring tuff sample, using a polyaxial cell. The maximum applied external boundary stresses are up to $20 \mathrm{MPa}$. No borehole breakouts have been observed. The sample has been subjected to uniaxial lateral stresses for the first two test series and to uniform lateral stresses for the last test series. Inconsistency of the strain results has been observed among the three test series, probably due to heterogeneity and inelasticity of the rock and due to separation of pre-existing microcracks or development of microcracks near the borehole wall when it is subjected to tangential tensile stress during uniaxial loading.

Biaxial borehole stability tests have been performed, using a lateral load frame, on seven Apache Leap tuff samples. The ratio of minimum to maximum applied boundary stresses varies from 0 to 0.29 . Test results indicate that rock density and stress ratio significantly affect the breakout stresses. The breakout stress is the tangential compressive 
stress at the borehole wall where breakouts are induced. Elastic analysis is used in this stress calculation. The breakout stresses vary from $130 \mathrm{MPa}$ for a sample with a density of $2.21 \mathrm{~g} / \mathrm{cc}$ and a stress ratio of 0 , to $568 \mathrm{MPa}$ for a sample with a density of $2.46 \mathrm{~g} / \mathrm{cc}$ and a stress ratio of 0.29 . This stress range is higher than the compressive strength of the tuff, determined by uniaxial compressive testing. The increase of breakout stress with density and stress ratio may be represented by an empirical equation:

$$
\begin{gathered}
\sigma_{\theta f}=(949 p-1994) \exp \left(2.05 \sigma_{H 2} / \sigma_{H 1}\right) \\
(\text { with } \rho \text { in } \mathrm{g} / \mathrm{cc})
\end{gathered}
$$

The depth and width of borehole breakouts are small and usually do not exceed a few millimeters.

Linear elastic analysis can not readily explain the variation of borehole strength with stress ratio. This could be due to the fact that Apache Leap tuff exhibits a nonlinear behavior near the peak stress or failure (Fuenkajorn and Daemen, 1991), and that the shape and size of the rock subjected to critical stresses in the breakout zones changes with stress ratio. The latter explanation relates to the effect of size and stress gradient on the rock strength (Jaeger and Cook, 1979, pp. 195-207).

The results from biaxial testing confirm that Apache Leap tuff is highly heterogeneous. Correction for the strength variation due to nonuniformity of the rock, by considering the bulk density, seems adequate. Nevertheless, the bulk density of the tuff block may not represent the density of the small volume of the rock in the breakout zone. This implication is supported by experimental evidence that the breakouts occur only in the soft inclusions, while the stronger rock matrix surrounding them remains intact. Flow layers in some Apache Leap tuff samples appear as weakness planes. These weakness planes significantly reduce the strength of the rock sample, and hence the strength of the rock around the borehole may not be as high as expected.

Biaxial borehole stability testing should be performed under a wide range of stress ratios and rock densities. Larger hole sizes should be tested to investigate the size effect. The maximum hole diameter should be at least 15 or $20 \mathrm{~cm}$. This would result in a large block specimen and would require a large high-capacity load frame. To prevent splitting in tension along the loading plane for a high stress ratio testing, the block sample should be confined in the axial direction. The axial load should be monitored so that the breakouts can be analyzed in three dimensions. A nonlinear elastic and/or plastic analysis should be performed in an attempt to explain the rock behavior in the breakout zones. 
CHAPTER ONE

INTRODUCTION

\subsection{Objective}

The objective of this research is to determine experimentally the stability and deformation of a circular borehole in welded tuff subjected to various external boundary loads. The stability of boreholes, or more generally of underground openings (i.e. Including shafts, ramps, drifts, etc.), at locations where seals are to be emplaced is an important consideration in seal design for a repository (Juhlin and Sandstedt, 1989). Borehole instability or borehole breakouts induced by stress redistribution could negate the effectiveness of seals or plugs. Fractures in the breakout zones along the wall of repository excavations or exploratory holes could provide a preferential flowpath for groundwater or gaseous radionuclides to bypass the plugs. After plug installation, the swelling pressure exerted by the plug could induce radial cracks or could open or widen preexisting cracks in the rock at the bottom of the breakouts where the tangential compressive stresses induced by the stressfield have been released by the breakout process. Finally, the effect of the high intrinsic variability of tuff properties (Fuenkajorn and Daemen, 1991) on the design of underground openings is of concern. Determination of the opening stability in such rock based upon one set of properties is questionable. Borehole stability testing provides a direct assessment of opening stability in these nonhomogeneous tuffs.

\subsection{Scope and Limitations}

The experimental work involves triaxial and biaxial borehole stability tests. The rock samples are prepared from densely welded Apache Leap tuff and Topopah Spring tuff. The maximum applied boundary stresses are up to the maximum load capacity of the available test machines. The axis of the borehole samples coincides with one of the principal stress axes. The borehole diameter is 13.3 or $14.4 \mathrm{~mm}$ for triaxial stability tests, and $25.4 \mathrm{~mm}$ for biaxial borehole stability tests. Experimental and analytical work is performed under nearly isothermal conditions (i.e. room temperature, $22-24^{\circ} \mathrm{C}$ ). All samples are tested dry. The boreholes have been drilled through the samples prior to applying the boundary stresses. The effect of borehole pressure is not studied.

\subsection{Organization}

This first chapter introduces the report, first by identifying the objective of this research, secondly by giving some aspects of instability and breakouts of boreholes, or, in general, underground openings, that have significant implications for the performance of geological nuclear waste repositories. The second section briefly states the scope as well as the limitations of the studies. This third section gives a chapter by chapter overview of the contents of this report. Section 1.4 
gives background on borehole breakouts, including questions which remain open in the breakout analysis and discrepancies between theories, experimental results and field observations. The fifth section gives the general characteristics of the rock samples and the locations from which they were obtained.

Chapter Two describes methods and results of borehole deformation and stability testing. Its first section identifies the specific objective of the experimental and analytical work. Method, results and discussion of triaxial borehole stability testing are given in Section 2.2. The third and fourth sections describe a biaxial borehole test using a polyaxial cell and a lateral load frame. Section 2.5 presents a discussion of the test results.

Chapter Three provides conclusions drawn from the borehole stability testing, as well as recommendations for future research. Appendices A through $D$ give procedures for triaxial and biaxial borehole deformation and stability tests, strain gage installation on a borehole wall, and biaxial borehole stability tests using a lateral load frame.

\subsection{Borehole Instability or Borehole Breakouts - Background}

Borehole breakouts are zones of spalling and fracture on opposite sides of a borehole (Mastin, 1988; Zoback et al., 1985). The failure zones elongate the borehole in cross-section from circular to approximately elliptical (Figure 1.1). The breakouts are generally formed by compressive failure of the rock at the borehole wall along the hole length where the compressive stress is greatest (Dhar et al., 1979; Gay, 1973, 1976; Gough and Bell, 1982). Factors influencing the stability of boreholes (Kaiser and Malony, 1987; Bandis and Barton, 1986; Guenot and Santare11i, 1988) are (1) rock strength and stiffness, including effects of anisotropy and fissuring, (2) stressfield - magnitudes of the three principal stresses, as well as their relative ratios and orientation with respect to the borehole axis, (3) drilling fluid characteristics density, temperature, and temperature change due to circulation (i.e including temperature gradients around boreholes), (4) influence of pore pressure and radial flow of fluid to or from the borehole, and (5) physico-chemical rock changes (Guenot, 1987). Combinations of these factors make analysis of the stability of deep boreholes difficult.

The major factors governing the development of borehole breakouts are the rock properties and the stressfield (Kaiser and Maloney, 1987; Guenot, 1989). Temperature gradients and fluid flow tend to enhance the breakout zones (Kaiser and Maloney, 1987; Guenot and Santare11i, 1988; Anderson et al., 1989). Analytical and experimental investigations of borehole instability have widely concentrated on the effects of stressfields and of rock properties (Gay, 1973, 1976; Biot, 1974; Haimson and Herrick, 1985; Cheatham et al., 1986; Santarelli et al., 1986; Zheng et al., 1988; Guenot, 1989) and do not consider the effects of the temperature gradients, fluid flow and anisotropy on the failure behavior of boreholes. The investigations are usually made such that the borehole axis is parallel to one of the principal stress axes. Deviations of the borehole axis from a principal stress axis can change the orientation of 


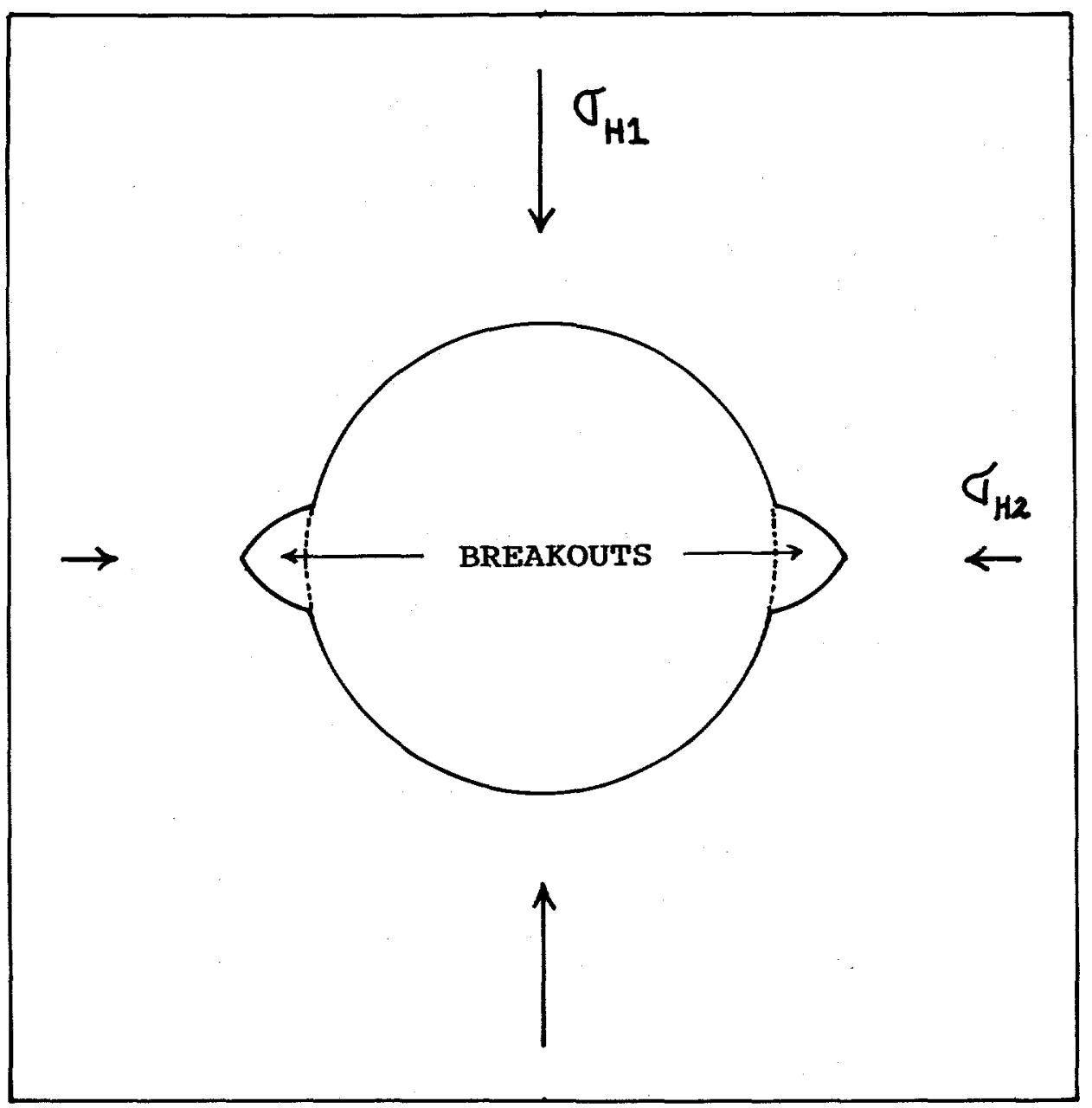

Figure 1.1 Borehole breakout orientation (after Mastin, 1988).

$\sigma_{H 1}, \sigma_{H 2}=$ major and minor principal stresses on the plane normal to borehole axis

(Reprinted with permission from Mastin, L., 1988, "Effect of Borehole Deviation on Breakout Orientation, "Journal of Geophysical Research, Vo1. 93, No. B8, Figure 1, p. 9187, Washington, DC) 
the breakout zones and the mode of failure around the hole wall (Mastin, 1988). The relationship between the angle of the borehole deviation and the orientation and failure mechanisms of the breakout zone is not unique nor simple. It is influenced by several combinations of the ratios, magnitudes and orientations of the principal stresses, the strength and stiffness of the rock, and by the ratios of the rock strength to the principal stresses. The orientation of a breakout zone also can change (i.e. not remain parallel to the minor principal stress axis on the borehole cross-section), even though one of the principal stress axes is parallel to the hole axis. Kaiser and Maloney (1987) have performed laboratory experiments and numerical analyses on the stability of a borehole subjected to polyaxial stresses with the major principal stress vertical and parallel to the borehole axis. They conclude that under conditions of high stress to strength ratios or of low horizontal stress ratios, or both, the orientation of the breakout zone deviates from the minor principal stress direction.

In general, breakouts occur in the borehole wall where the tangential compressive stress reaches a maximum. The orientation of the breakout zones in deep vertical boreholes has therefore been used to determine the direction of the principal horizontal stresses (Turchaninov et al., 1979, pp. 204-208; Guenot, 1989; Zoback and Healy, 1989). The results usually agree with those obtained from hydraulic fracturing. Zheng et al. (1988) have shown, by means of numerical methods, that the effects of breakout zones on hydraulic fracturing measurements are insignificant. In practice, it would be difficult to set packers for hydraulic fracturing in holes with extensive breakouts. Similarly, seals emplaced in locations with significant, or even incipient, breakouts are likely to be compromised by bypass flow.

The possibility of obtaining information about the state of stress in a rock mass by observing spalling of boreholes and underground excavations has long been recognized in the mining and underground construction industries (e.g. Isaacson, 1958, p. 58; Hoek, 1964, 1965; Leeman, 1965, Sperry and Heurer, 1972; Turchaninov et a1., 1979, pp. 206-207; Hoek and Brown, 1980, pp. 212-215; Beus and Chan, 1982). More recently the method has been pursued for the development of a more detailed understanding of the stress state based on fracture orientations (Be11 and Gough, 1982; Kozlovsky, 1984).

The traditional explanation of the observed shape of breakouts is based on the logarithmic spirals corresponding to the preferred failure directions around a circular opening in an isotropic stressfield (e.g. Isaacson, 1958, p. 56; Jaeger and Cook, 1979, Sections 6.8, 9.4, 16.5; Rabcewicz, 1964-5). Laboratory studies confirm the general shape and diametrical position of breakouts in hydrostatic loading (normal to the hole axis) (e.g. Daemen and Fairhurst, 1971; Jamet, 19731) and in biaxial loading (e.g. Sperry and Heuer, 1972).

1 Jamet, P., 1973, "Compressive Failure of a Hollow Cylinder Subjected to External Loading," MS Thesis, University of Minnesota, Minneapolis, $\mathrm{vi}+107 \mathrm{pp}$. 
Jaeger and Cook argue that elastic overstress calculations can provide considerable insight into expected fracture patterns. Hoek (1965) and Hoek and Brown (1980) strongly emphasize the need for taking into account the stress redistribution associated with fracture propagation.

The limit shear strength analysis developed by Rabcewicz (1964-65) for design of tunnel support systems could be used as one of the analysis procedures, because it provides a limit load at failure, by means of a simplified integration.

Energy density distribution calculations (Black and Starfield, 1964) suggest shapes of spalls corresponding closely to spalling initiation and fracture propagation observed in earlier experiments (e.g. Daemen and Fairhurst, 1970; Heurer and Hendron, 1971; Sperry and Heuer, 1972; Jamet, $1973^{2}$ ). It would seem logical therefore to pursue this approach to the back-anlysis of observed results. The same holds true for analysis by means of excess stress contours (e.g. Jaeger and Cook, 1979, Section 18.10; Bieniawski and Bauer, 1982).

Several attempts have been made at correlating the sizes and shapes (width, depth and angle of fractures) of breakouts to the magnitude and ratio of the principal stresses in the plane normal to the borehole (Zoback et al., 1985; Ewy et al., 1988; Guenot and Santarel1i, 1988). The results have not yet been conclusive. The relationship between the breakout characteristics and the magnitude and ratio of the principal stress is not unique for a certain rock (Zheng et al., 1988). Governing the stress-induced breakouts are not only the rock properties and magnitudes and ratios of the principal stresses, but also the rate of loading (Kaiser and Maloney, 1987). The rate at which field stresses concentrate around a borehole involves the penetration rate of drilling for an in-situ condition, and the loading rate for laboratory experiments. From the results of numerical analyses, zheng et al. (1988) conclude that the breakouts produced by slowly increasing stresses are much smaller than those from rapidly increasing stress, even when the final stress values are the same. This is because the initial breakout angle (the arc on the borehole boundary which the breakout occupies) is small when the initial stresses are small, and the breakout shape relieves the stresses at points behind this arc before the far field stresses reach their final values. The effect of the stress path on the borehole breakouts has also been observed by Stacey and de Jongh (1977).

Another factor that probably involves the breakout characteristics but has rarely been addressed is the time-dependent deformation and failure of the rock (Kaiser and Maloney, 1987; Kaiser et al., 1985; Cheatham et al., 1986). Most rocks exhibit more or less time-dependent deformation, particularly under high confining pressures. It has been shown experimentally that propagation (growth) of fractures in geologic materials under differential stresses is time-dependent (Gramberg, 1965; Kranz,

2 Jamet, P., 1973, "Compressive Failure of a Hollow Cylinder Subjected to External Loading," MS Thesis, University of Minnesota, Minneapolis, vi $+107 \mathrm{pp}$. 
1979, 1983; Horii and Nemat-Nasser, 1985, Costin, 1987). The breakout process may continue for some time after a hole has been drilled. Timedependent propagation of breakouts has been observed for some Canadian boreholes which have been logged twice (Be11 and Gough, 1982). The second log runs recorded increases in depth of breakouts and, in some cases, increases in breakout length along the hole walls.

The mechanisms governing fracture growth around a borehole in rock subjected to a stressfield are not clearly understood (Hoek and Brown, 1980, p. 215; Haimson and Herrick, 1985; Kaiser et al., 1985; Bandis and Barton, 1986; Ewy et al., 1988). Daemen and Fairhurst (1971) found no indications of fracturing around the borehole when the external hydrostatic pressures applied to thick-walled hollow cylinders of Indiana limestone and concrete reached levels at which linear elastic analysis gives tangential stresses at the borehole wall of at least four times the measured uniaxial compressive strength of the material. Final collapse occurred at even higher pressures. Similar apparent strength enhancement has been recorded in hollow cylinder tests by Santarelli and Brown (1987) and Guenot (1989). The elastic stresses calculated at the borehole wall are found to be higher than the strengths given by a peak strength criterion determined from the results of triaxial compression tests. Guenot (1987) has tabulated results from ten authors on some seven rock types. The ratio between the maximum (elastically) calculated compressive stress at which failure occurs and the uniaxial compressive strength typically is about two.

Several explanations have been offered for these seemingly anomalous observations. According to elastic theory, the borehole wall is in a high stress gradient which may influence the fracture propagation. The apparent inconsistency may also be influenced by size effects; in 1aboratory studies, the critically stressed volume of rock at the borehole wall is usually significantly smaller than that of the specimens used in strength determination. It is also possible that for the nonhydrostatic tests, a strength criterion determined from triaxial compression tests may not allow adequately for the influence of the intermediate principal stress. The rock adjacent to a borehole is generally under polyaxial stress in plane strain, with only one surface that can dilate. It is subjected to stress and strain gradients, and is loaded by adjacent rock rather than by a testing machine (Ewy et al., 1988). Finally, and perhaps most obviously, the failure stresses calculated assuming linear elasticity with constant elastic parameters may be inaccurate. The pre-yield and pre-peak stress-strain relations of some rocks are nonlinear and the elastic properties are pressure-dependent (Santarelli et al., 1986).

Several concepts supported by numerical analyses, laboratory experiments and field observations have been developed to describe the failure mechanisms, fracture growth and constitutive behavior of the rock in breakout zones (Guenot and Santarel1i, 1988; Bandis and Barton, 1986; Kaiser and Kwong, 1988; Maury, 1987; Gough and Bell, 1982; Cheatham et al., 1986). These concepts can be divided into two approaches: developing the constitutive models of the rock before and after the breakouts have been initiated, and developing the failure criteria of the rock. In 
general, a constitutive model analysis of the rock describes the stress and strain distributions around the borehole in a stressfield. A failure criterion determines the location and extent of the breakout zones. The failure mechanisms determine the patterns (orientations) of the cracks or fractures progressively induced by the stresses and forming the breakout zones.

\subsection{Source Locations and General Description of Tuff Samples}

Rock samples used in the borehole stability testing are from the densely welded brown unit of the Apache Leap tuff and from Topopah Spring tuff. The Apache Leap tuff samples are collected along $01 d$ Highway 60 , about 2.5 miles northeast of Superior, Arizona. Evans (1983) and Vogt (1988) describe the geology of the area and the origin of the rock. South and Daemen (1986, pp. 66-69) give the location near the Nevada Test Site where the Topopah Spring tuff samples have been obtained. Fuenkajorn and Daemen (1991) give the mechanical and petrographical properties of both tuffs and discuss similarities and differences between the rocks. 
CHAPTER TWO

\section{BOREHOLE STABILITY TESTING}

\subsection{Introduction}

The purpose of this investigation is to evaluate the stability and deformation of a circular hole in a tuff specimen subjected to various external boundary loads. The experimental work involves triaxial, biaxial and uniaxial borehole stability tests. The boreholes are subjected to stressfields that vary from uniform (isotropic) loading (where $\sigma_{H 1}=\sigma_{H 2}=\sigma_{V}$ ) to uniaxial loading (where $\sigma_{H 2}=\sigma_{V}=0$ ). The boundary loads are progressively increased until breakouts occur or until the maximum load capacity of the loading system has been reached.

\subsection{Triaxial Borehole Stability Testing}

\subsubsection{Test Method and Sample Preparation}

The triaxial borehole stability testing determines the deformation and stability of a borehole in a tuff cylinder subjected to uniform lateral and axial loads. The hollow cylinder samples are prepared from Apache Leap tuff. The nominal dimensions are $50 \mathrm{~mm} \mathrm{O.D.,} 13 \mathrm{~mm} \mathrm{I.D.} \mathrm{and} 100 \mathrm{~mm}$ length. The samples have been tested in isotropic stress conditions. The axial and lateral stresses are progressively increased up to $42 \mathrm{MPa}$. The axial and circumferential strains on the borehole wall are measured for every $10 \mathrm{MPa}$ (approximately) stress increment. Appendix A gives the test procedure and sample specifications. Appendix B gives a method to install electrical resistance strain gages on the inside wall of the test hole. Two samples have been tested. Figures 2.1 and 2.2 give their dimensions.

\subsubsection{Results from Triaxial Borehole Stability Testing}

\subsubsection{Sample AP22-3-2-BS1}

Table 2.1 gives the lateral stress, axial load, and strain reading (in microstrains) for each gage, at each loading step. Three loading cycles have been made. The first cycle was cut short because the plastic membrane confining the sample had broken. Following the test, the sample was cut longitudinally, in order to examine the gage installation. Gage \#1 was not bonded to the borehole wall at all points so results from this gage are not valid.

The maximum lateral stress on the last cycle is $41.4 \mathrm{MPa}$. No breakouts from the borehole wall have been observed. Figures 2.3 and 2.4 give the axial strain and the lateral strain, for three load cycles, as a function of lateral stress, respectively. Both axial and lateral strains increase linearly with increasing lateral stress, and can be represented by: 


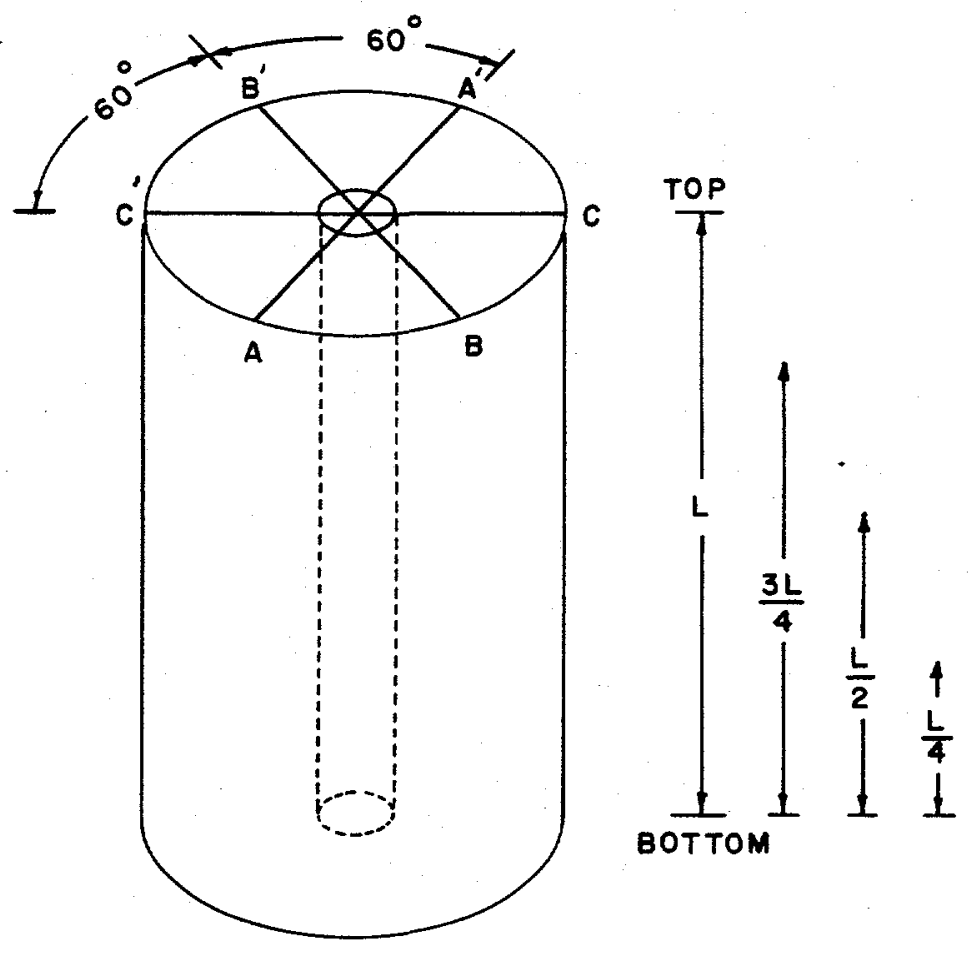

\begin{tabular}{|c|c|c|c|c|c|c|}
\hline \multirow{2}{*}{\multicolumn{2}{|c|}{ DIAMETERS }} & \multicolumn{5}{|c|}{ POSITIONS } \\
\hline & & TOP , L & $\frac{3 L}{4}$ & $\frac{L}{2}$ & $\frac{L}{4}$ & BOTTOM \\
\hline $\begin{array}{l}\text { لٌ } \\
\stackrel{1}{1}\end{array}$ & $\begin{array}{l}A A^{\prime} \\
B B^{\prime} \\
C C^{\prime}\end{array}$ & $\begin{array}{l}=13.3 \\
=13.3 \\
=13.3\end{array}$ & & & $\begin{array}{l}= \\
= \\
=\end{array}$ & $\begin{array}{l}=13.4 \\
=13.3 \\
=13.4\end{array}$ \\
\hline 总 & $\begin{array}{l}A A^{\prime} \\
B B^{\prime} \\
C C^{\prime}\end{array}$ & $\begin{array}{l}=50.6 \\
=50.6 \\
=50.6\end{array}$ & $\begin{array}{l}=50.6 \\
=50.6 \\
=50.6\end{array}$ & $\begin{array}{l}=50.6 \\
=50.6 \\
=50.6\end{array}$ & $\begin{array}{l}=50.6 \\
=50.6 \\
=50.6\end{array}$ & $\begin{array}{l}=50.6 \\
=50.6 \\
=50.5\end{array}$ \\
\hline
\end{tabular}

All dimensions are in $\mathrm{mm}$.

Figure 2.1 Dimensions of sample AP22-3-2-BS1, prepared from Apache Leap tuff for triaxial borehole stability test. 


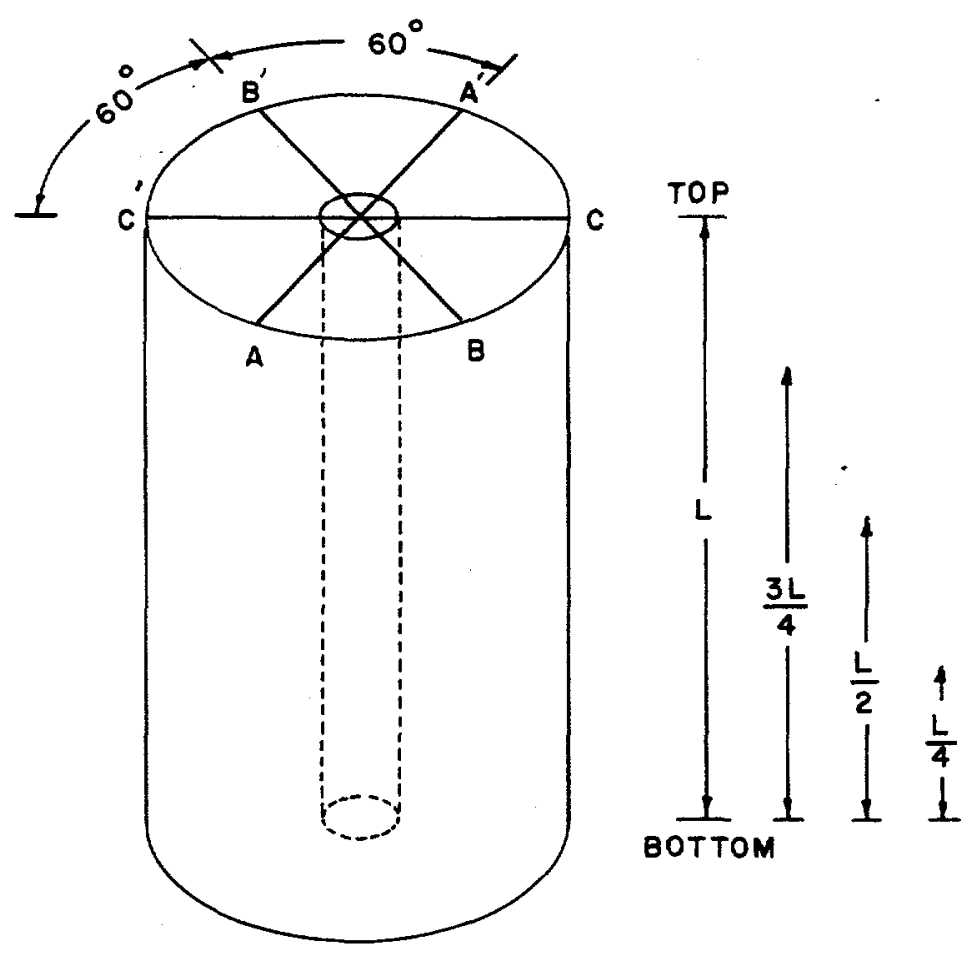

\begin{tabular}{|c|c|c|c|c|c|c|}
\hline & & & & POSITIONS & & \\
\hline & IETERS & TOP , L & $\frac{3 L}{4}$ & $\frac{L}{2}$ & $\frac{L}{4}$ & BOTTOM \\
\hline$\frac{w}{\partial}$ & $\begin{array}{l}A A^{\prime} \\
B B^{\prime} \\
C C^{\prime}\end{array}$ & $\begin{array}{l}=14.4 \\
=14.4 \\
=14.4\end{array}$ & $\begin{array}{l}= \\
= \\
=\end{array}$ & & $\begin{array}{l}= \\
= \\
=\end{array}$ & $\begin{array}{l}=14.4 \\
=14.4 \\
=14.4\end{array}$ \\
\hline$\frac{\substack{\frac{n}{u} \\
\frac{1}{j}}}{j}$ & $\begin{array}{l}A A^{\prime} \\
B B^{\prime} \\
C C^{\prime}\end{array}$ & $\begin{array}{l}=50.6 \\
=50.6 \\
=50.6\end{array}$ & $\begin{array}{l}=50.6 \\
=50.6 \\
=50.6\end{array}$ & $\begin{array}{l}=50.6 \\
=50.6 \\
=50.7\end{array}$ & $\begin{array}{l}=50.6 \\
=50.6 \\
=50.6\end{array}$ & $\begin{array}{l}=50.6 \\
=50.6 \\
=50.6\end{array}$ \\
\hline
\end{tabular}

Al1 dimensions are in $\mathrm{mm}$.

Figure 2.2 Dimensions of sample AP22-4-2-BS2, prepared from Apache Leap tuff for triaxial borehole stability test. 
Table 2.1 Triaxial Test Results: Sample AP-22-3-2-BS1

\begin{tabular}{|c|c|c|c|c|c|c|c|}
\hline \multirow[b]{3}{*}{ Trial } & \multirow[b]{3}{*}{ Step } & \multirow[b]{3}{*}{$\begin{array}{l}\text { Lateral } \\
\text { Stress } \\
\text { (MPa) }\end{array}$} & \multirow[b]{3}{*}{$\begin{array}{l}\text { Axial } \\
\text { Load } \\
\text { (kN) }\end{array}$} & \multicolumn{4}{|c|}{ Strain Readings } \\
\hline & & & & & (micros & ains) & \\
\hline & & & & $\begin{array}{l}\text { Gage } 1 \\
\text { Axial } \\
\text { Strain* }\end{array}$ & $\begin{array}{l}\text { Gage } 2 \\
\text { Axial } \\
\text { Strain }\end{array}$ & $\begin{array}{l}\text { Gage } 1 \\
\text { Lateral } \\
\text { Strain* }\end{array}$ & $\begin{array}{l}\text { Gage } 2 \\
\text { Lateral } \\
\text { Strain }\end{array}$ \\
\hline 1 & 0.1 & 0 & 0 & 0 & 0 & 0 & 0 \\
\hline 1 & 0.2 & 0 & 0.9 & -12 & -18 & -19 & -2 \\
\hline$\overline{1}$ & 1.1 & 10.0 & 20.1 & 94 & -156 & -513 & 40 \\
\hline 2 & 0.0 & 0 & 0 & 0 & 0 & 0 & 0 \\
\hline 2 & 0.1 & 0 & 0.9 & -19 & -16 & -12 & -5 \\
\hline 2 & $0.1 * \star$ & 0 & 0.9 & -151 & -53 & -40 & -165 \\
\hline 2 & 1.1 & 10.0 & 19.8 & -43 & -242 & -504 & -173 \\
\hline 2 & 2.1 & 20.0 & 41.4 & 64 & -442 & -971 & -161 \\
\hline 2 & 3.1 & 30.0 & 64.5 & 193 & -593 & -1488 & -146 \\
\hline 3 & 0.0 & 0 & 0 & 0 & 0 & 0 & 0 \\
\hline 3 & 0.1 & 0 & 0.9 & -3 & -24 & -9 & -5 \\
\hline 3 & 1.1 & 10.0 & 19.6 & 136 & -200 & -486 & -16 \\
\hline 3 & 2.1 & 20.0 & 40.9 & 282 & -402 & -990 & -9 \\
\hline 3 & 3.1 & 30.0 & 63.6 & 408 & -600 & -1412 & 49 \\
\hline 3 & 4.1 & 41.4 & 85.4 & 542 & -824 & -2120 & 52 \\
\hline
\end{tabular}

*Quality of bonding suspect, as revealed by post-testing gage inspection. Results are questionable.

**Instrumentation drift occurred at this step. 


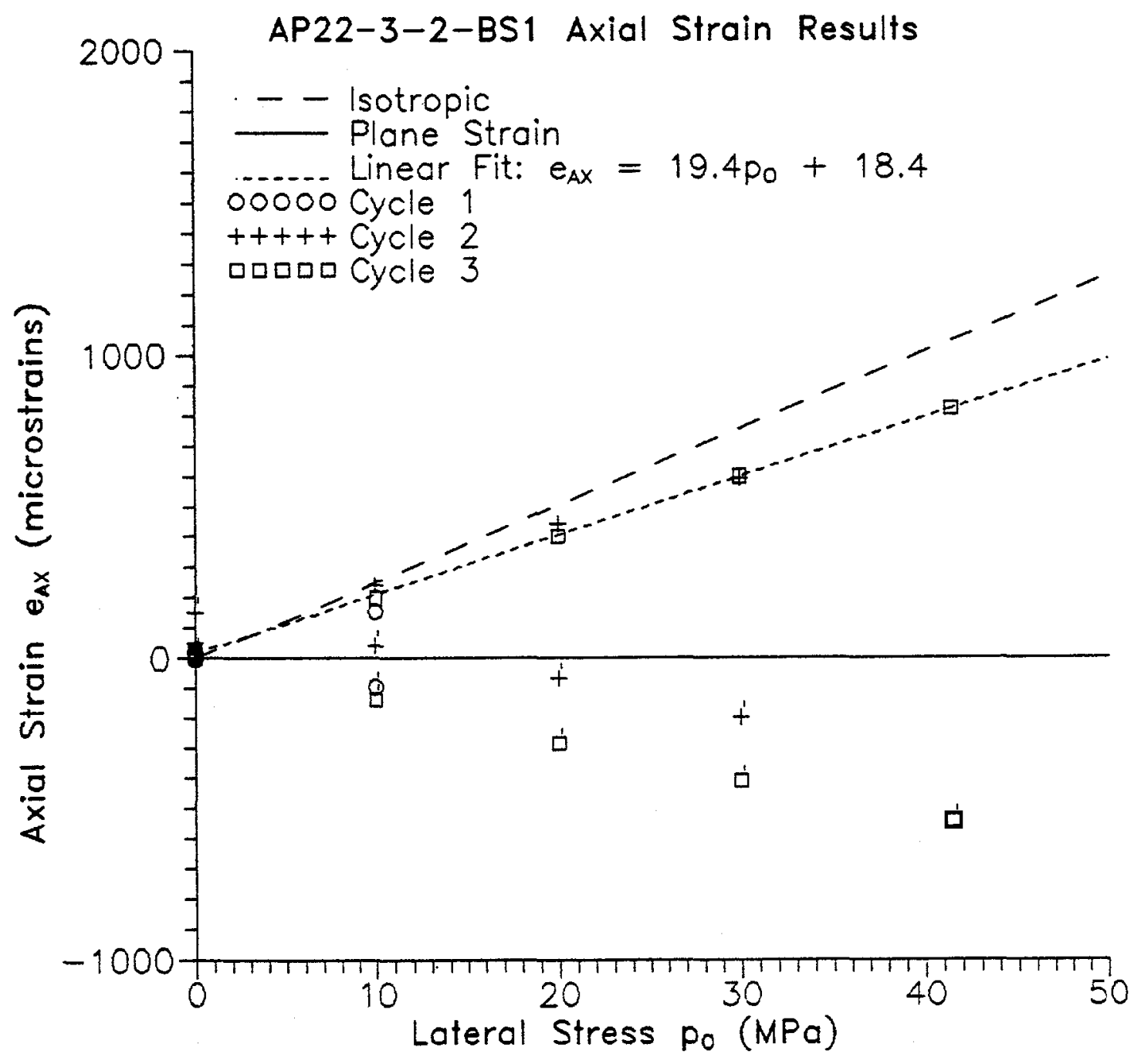

Figure 2.3 Isotropic and plane strain solutions plotted with axial strain test data and linear best fit for sample AP22-3-2-BS1, as a function of lateral stress. (Plane strain solution lies on $x$-axis.) Three cycles were run. Data points marked with ticks are from unreliable gage results. Residual strain measurements at the end of each cycle are included. 


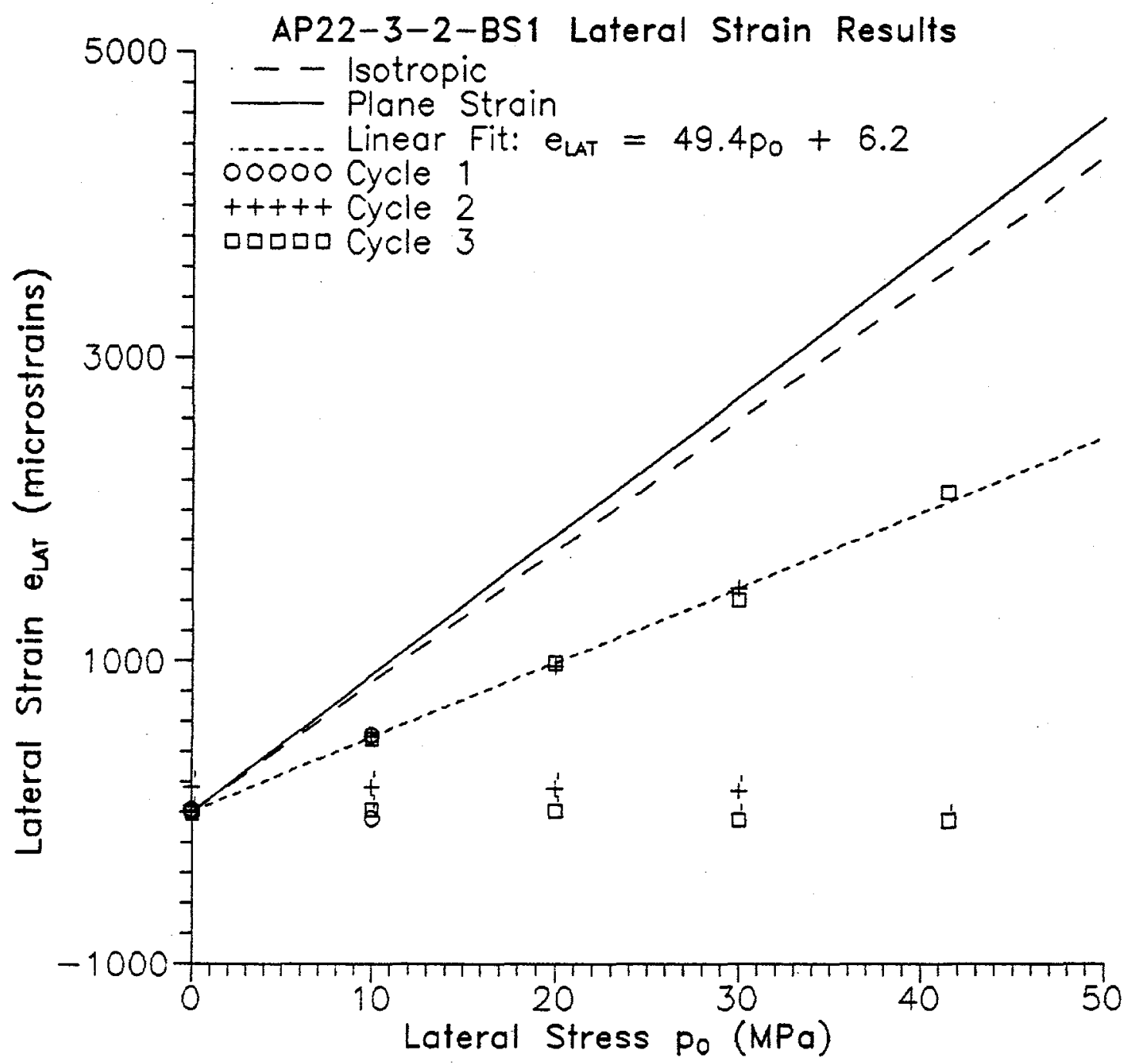

Figure 2.4 Isotropic and plane strain solutions plotted with lateral strain test data and linear best fit for sample AP22-3-2-BS1, as a function of lateral stress. (Plane strain solution lies on $x$-axis.) Three cycles were run. Data points marked with ticks are from unreliable gage results. Residual strain measurements at the end of each cycle are included. 


$$
\epsilon_{z}=19.4 P_{0}+18.4
$$

and

$$
\epsilon_{\theta}=49.4 P_{0}+6.2
$$

where $\epsilon_{x}=$ axial strain (in microstrains)

$\epsilon_{\theta}=$ lateral (or circumferential) strain (in microstrains)

$P_{0}=$ lateral and axial stress (in MPa).

\subsubsection{Sample AP22-4-2-BS2}

Table 2.2 gives the results for four loading cycles of sample AP22-4-2BS2. The maximum axial and lateral stresses are about $42 \mathrm{MPa}$. No breakout has been observed. Unloading measurements are made at the final step of cycles 非, 3 and 4. Permanent deformations (axial and lateral strains) have been observed from these cycles.

Figures 2.5 and 2.6 give the axial and lateral strains measured on the borehole wall, as a function of lateral stress. Averaging from all cycles, the strains tend to increase linearly with stress. Regression analyses on the test results give the following relations:

$$
\epsilon_{z}=17.7 P_{0}+24.7
$$

and

$$
\epsilon_{\theta}=59.5 P_{0}+6.0
$$

where $\epsilon_{z}=$ axial strain (in microstrains)

$\epsilon_{\theta}=$ lateral strain (in microstrains)

$P_{0}=$ applied pressure (in $\mathrm{MPa}$ ).

\subsubsection{Discussion}

The boreholes are stable under uniform lateral stress up to $42 \mathrm{MPa}$. At this maximum applied stress, the elastic solution gives a tangential compressive stress, at the borehole wall, of $84 \mathrm{MPa}$. This compressive stress exceeds the average uniaxial compressive strength of the tuff, given by Fuenkajorn and Daemen (1991) as $73 \mathrm{MPa}$. The relationship between the applied stress and the resulting strain seems to be linear for all loading cycles. This implies that under a uniform applied stress up to $42 \mathrm{MPa}$, the elastic solution used in the calculation of the stresses around the borehole may be valid. 
Table 2.2 Triaxial Borehole Stability Test Results: Sample AP-22-4-2-BS2

\begin{tabular}{|c|c|c|c|c|c|c|c|}
\hline \multirow[b]{3}{*}{ Trial } & \multirow[b]{3}{*}{ step } & \multirow[b]{3}{*}{$\begin{array}{c}\text { Lateral } \\
\text { Stress } \\
\text { (HPa) }\end{array}$} & \multirow[b]{3}{*}{$\begin{array}{l}\text { Axial } \\
\text { Stress } \\
\text { (MPa) }\end{array}$} & \multicolumn{4}{|c|}{ Strain Readings } \\
\hline & & & & & (micros & ains) & \\
\hline & & & & $\begin{array}{l}\text { Gage } 1 \\
\text { Latera1 } \\
\text { Strain }\end{array}$ & $\begin{array}{l}\text { Gage } 2 \\
\text { Axial } \\
\text { strain }\end{array}$ & $\begin{array}{l}\text { Gage } 3 \\
\text { Lateral } \\
\text { Strain }\end{array}$ & $\begin{array}{l}\text { Gage } 4 \\
\text { Axial } \\
\text { Strain }\end{array}$ \\
\hline \multirow[t]{3}{*}{1} & 0.0 & 0 & 0 & 0 & 0 & 0 & 0 \\
\hline & 0.1 & 0 & .7 & -5 & -19 & -7 & 27 \\
\hline & 1.0 & 10.0 & 9.6 & 617 & 236 & 553 & 222 \\
\hline \multirow[t]{8}{*}{2} & 0.0 & 0 & 0 & 0 & 0 & 0 & 0 \\
\hline & 0.1 & 0 & 0.2 & -3 & 18 & -6 & 28 \\
\hline & 1.0 & 9.7 & 9.4 & 578 & 194 & 516 & 190 \\
\hline & 2.0 & 20.0 & 20.1 & 1222 & 402 & 1118 & 365 \\
\hline & 3.0 & 30.0 & 31.1 & 1901 & 605 & 1610 & 531 \\
\hline & 4.0 & 34.5 & 36.0 & 2179 & 693 & 1957 & 613 \\
\hline & 4.1 & 41.4 & 43.1 & 2701 & 838 & 2319 & 731 \\
\hline & 5.0 & 0 & 0 & 138 & 47 & 54 & 49 \\
\hline \multirow[t]{8}{*}{3} & 0.0 & 0 & 0 & 0 & 0 & 0 & 0 \\
\hline & 0.1 & 0 & 0.4 & & & & \\
\hline & 1.0 & 10.0 & 9.7 & 624 & 217 & 573 & 203 \\
\hline & 2.0 & 20.0 & 20.1 & 1235 & 411 & 1121 & 361 \\
\hline & 3.0 & 30.0 & 30.4 & 1847 & 598 & 1694 & 524 \\
\hline & 4.0 & 34.5 & 35.5 & 2149 & 685 & 1956 & 594 \\
\hline & 4.1 & 41.4 & 42.6 & 2585 & 817 & 2365 & 703 \\
\hline & 5.0 & 0 & 0 & 30 & 31 & 14 & 33 \\
\hline \multirow[t]{8}{*}{4} & 0.0 & 0 & 0 & 0 & 0 & 0 & 0 \\
\hline & 0.1 & 0 & .4 & 0 & 7 & -1 & 9 \\
\hline & 1.0 & 10.0 & 9.7 & 622 & 196 & 564 & 171 \\
\hline & 2.0 & 20.0 & 20.0 & 1250 & 392 & 1128 & 331 \\
\hline & 3.0 & 30.0 & 30.6 & 1856 & 578 & 1698 & 489 \\
\hline & 4.0 & 34.5 & 35.5 & 2154 & 667 & 1959 & 558 \\
\hline & 4.1 & 41.4 & 41.9 & 2575 & 793 & 2364 & 667 \\
\hline & 5.0 & 0 & 0 & 30 & 21 & 6 & 19 \\
\hline
\end{tabular}




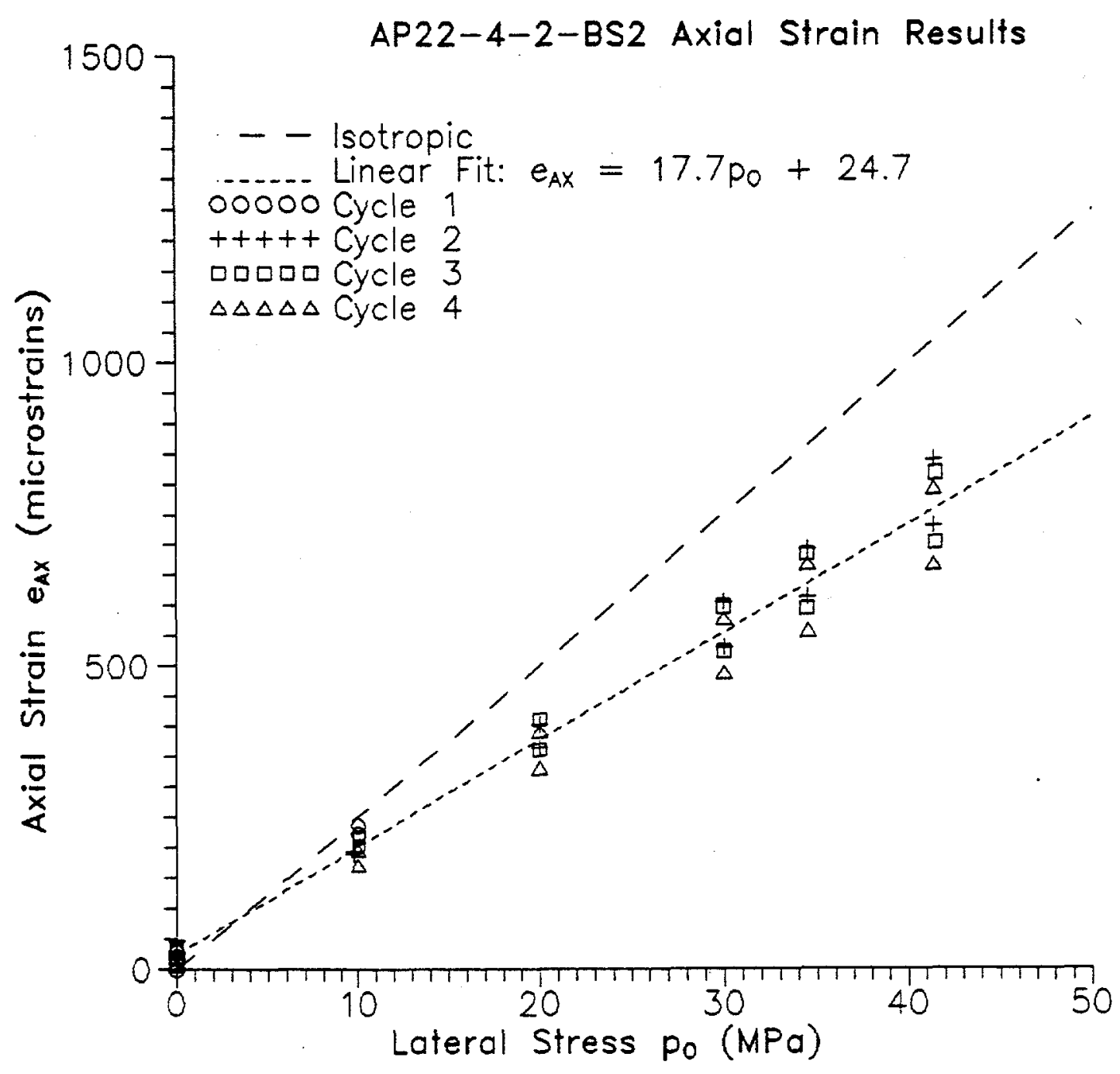

Figure 2.5 Isotropic and plane strain solutions plotted with axial strain test data and linear best fit for sample AP22-4-2$B S 2$, as a function of lateral stress. (Plane strain solution lies on $x$-axis.) Four cycles were run. Data points for gage location 1 generally fall above the linear fit, while those for location 2 fall below. Residual strain measurements at the end of each cycle are included. 


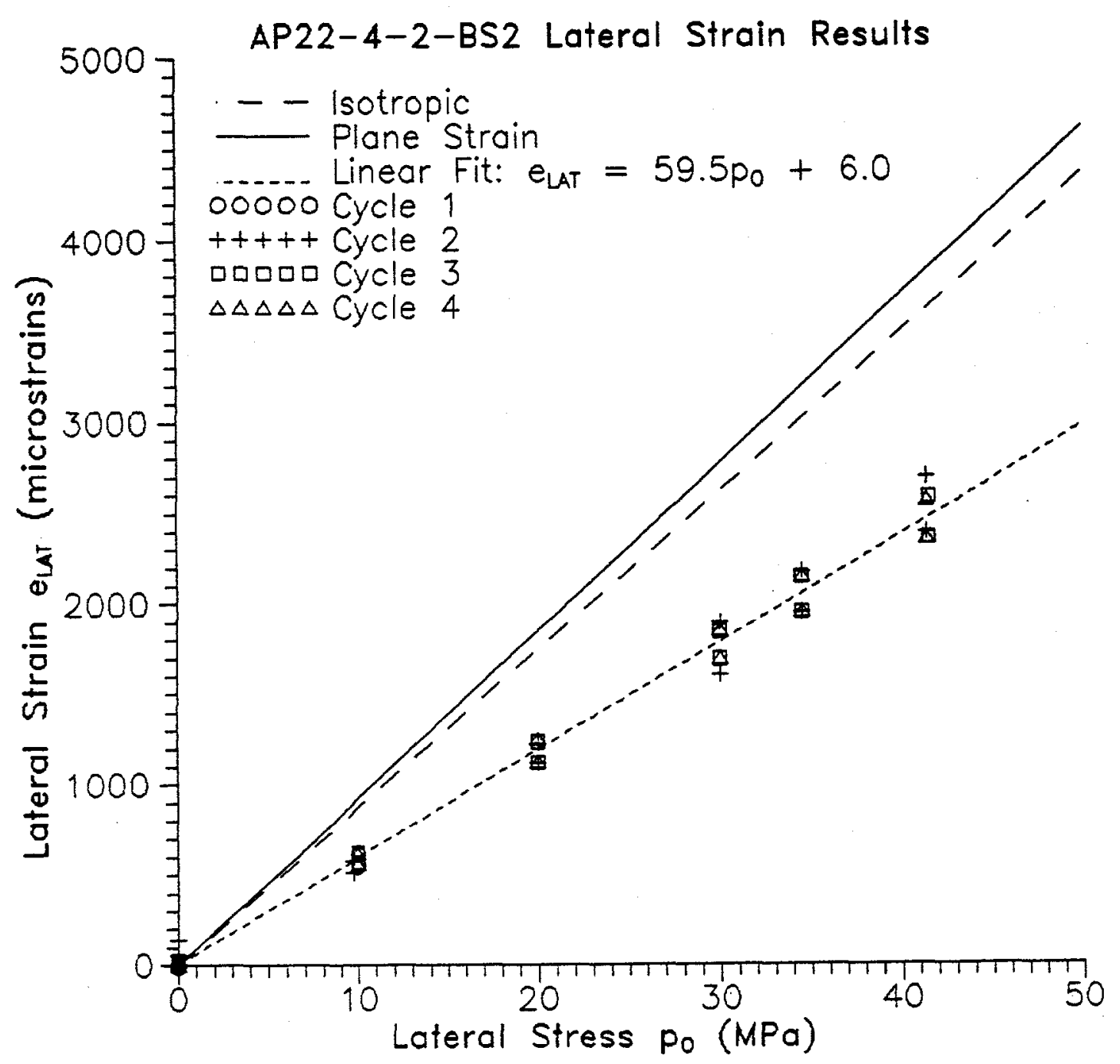

Figure 2.6 Isotropic and plane strain solutions plotted with lateral strain test data and linear best fit for sample AP22-4-2BS2, as a function of lateral stress. (P1ane strain solution lies on $x$-axis.) Four cycles were run, Data points for gage location 1 generally fall above the linear fit, while those for location 2 fall below. Residual strain measurements at the end of each cycle are included. 


\subsection{Biaxial Borehole Stability Testing - Using Polyaxial Cell}

\subsubsection{Test Method and Sample Preparation}

The biaxial borehole stability test using a polyaxial cell determines the deformation and stability of a borehole in a tuff block subjected to lateral loads. The block specimen has been prepared from Topopah Spring tuff. The nominal dimensions of the block are $100 \times 100 \times 200 \mathrm{~mm}$, with a $2.5 \mathrm{~cm}$ diameter coaxial hole. The sample has been tested under uniform lateral stresses and under a uniaxial lateral stress. The sample has not been confined in the axial direction. The applied stresses are progressively increased up to $20 \mathrm{MPa}$. The axial and circumferential strains on the borehole wall in the principal stress axes are measured for every $5 \mathrm{MPa}$ (approximately) stress increment. Appendix $\mathrm{C}$ gives the test procedure and sample specifications. The method for installing strain gages on the wall of the test hole is given in Appendix $B$.

\subsubsection{Test Results}

Three series of loading have been made. The maximum applied stresses for each series are nearly $20 \mathrm{MPa}$. No borehole breakouts have been observed. All strain gages have been adjusted to obtain a zero reading before loading is begun. Unloading strains have been recorded for the first two series of loading. Table 2.3 gives the measured lateral and axial strains and the applied stress. Figure 2.8 gives locations of the strain gages, with respect to loading directions. Figures 2.9 through 2.11 give measured strains as a function of applied stresses in the $\mathrm{x}$-direction, $\mathrm{y}$-direction, and the $\mathrm{x}$ - and $\mathrm{y}$-directions, respectively.

\subsubsection{Discussion}

Inconsistency of the strain results has been observed during three test series. This is probably due to a combination of inadequate gage bonding, heterogeneity and inelasticity of the Topopah Spring tuff, and separation of pre-existing microcracks near the borehole wall when it is subjected to tangential tensile stresses. For the first test series, the uniaxial lateral stresses are applied in the $\mathrm{x}$-direction (Figure 2.9). Strain gages 1,2 and 4 give reasonable results, i.e. increase in compression for gages 1 and 2 , and increase in tension for gage 4. Strain gage 3 does not increase in tension after the applied stress exceeds $10 \mathrm{MPa}$. This may be caused by a development of microcracks near the gage due to the tangential tensile stresses. A similar phenomenon probably influences gage 4 during the second test series, when the uniaxial lateral stresses are applied in the y-direction (Figure 2.10). In this test series, gage 3 shows less compressive strain than does gage 1 . Gage 1 shows a large permanent compressive strain after unloading. This is probably due to inelasticity of the tuff.

The sample is subjected to a uniform lateral stress in the last test series (Figure 2.11). Gages 1,3 and 4 show an increase in compressive strains with the applied stress, while gage 2 shows an increase in tensile strain. This implies that the rock is not homogeneous. The increase of the strains measured from gages 1,3 and 4 seems to be 


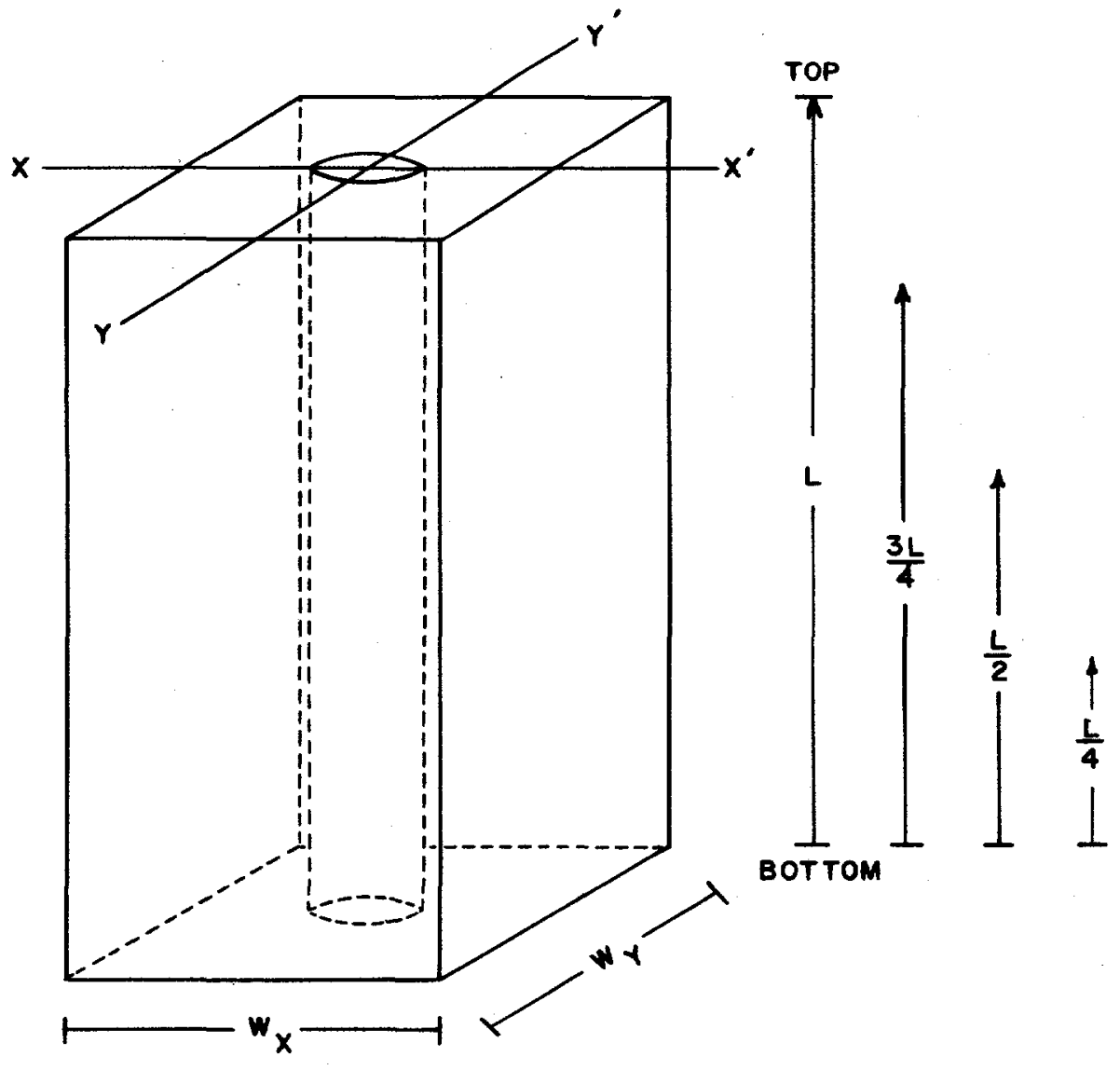

\begin{tabular}{|c|c|c|c|c|c|c|}
\hline & & \multicolumn{5}{|c|}{ POSITIONS } \\
\hline & & TOP: L & $\frac{3 L}{4}$ & $\frac{L}{2}$ & $\frac{L}{4}$ & BOTTOM \\
\hline $\begin{array}{c}\text { HOLE } \\
\text { OIAMETER }\end{array}$ & $\begin{array}{l}D_{X} \\
D_{Y}\end{array}$ & $\begin{aligned} & 200 \mathrm{~mm} \\
= & 26.4 \\
= & 26.5\end{aligned}$ & $\begin{array}{l}=26.4 \\
=26.4\end{array}$ & $\begin{array}{l}=26.4 \\
=26.4\end{array}$ & $\begin{array}{l}=26.4 \\
=26.4\end{array}$ & $\begin{array}{l}=26.5 \\
=26.5\end{array}$ \\
\hline $\begin{array}{l}\text { SAMPLE } \\
\text { WIDTH }\end{array}$ & $\begin{array}{l}w_{x} \\
w_{r}\end{array}$ & $\begin{array}{l}=98.20 \\
=99.19\end{array}$ & $\begin{array}{l}=98.22 \\
=99.19\end{array}$ & $\begin{array}{l}=98.20 \\
=99.16\end{array}$ & $\begin{array}{l}=98.17 \\
=99.16\end{array}$ & $\begin{array}{l}=98.20 \\
=99.14\end{array}$ \\
\hline
\end{tabular}

All dimensions are in $\mathrm{mm}$.

Figure 2.7 Dimensions of sample TPS-PX1, prepared from Topopah Spring tuff for polyaxial borehole stability test. 
Table 2.3 Results of Biaxial Borehole Deformation and Stability

Tests: Sample TPS-PX1 (Topopah Spring Tuff)

\section{Strain (microstrains)}

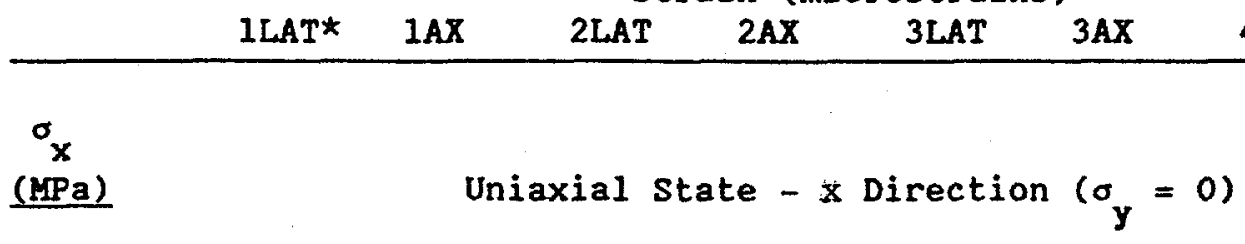

$\begin{array}{rrrrrrrrr}0.00 & 0 & 0 & 0 & 0 & 0 & 0 & 0 & 0 \\ 4.83 & -398 & -119 & 669 & 8 & -391 & -146 & 589 & -33 \\ 10.00 & -1003 & -305 & 1404 & -43 & -954 & -349 & 1208 & -110 \\ 15.17 & -2489 & 310 & 2943 & -29 & -634 & -269 & 2506 & -126 \\ 19.99 & -4145 & 361 & 4081 & -48 & -587 & -394 & 3422 & -163 \\ 0.00 & 413 & 395 & 221 & 12 & -152 & 19 & 231 & -16\end{array}$

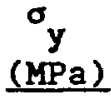

$\begin{array}{rrrrrrrrr}0.00 & 0 & 0 & 0 & 0 & 0 & 0 & 0 & 0 \\ 4.83 & 1775 & -98 & -502 & -83 & 877 & 70 & -380 & -40 \\ 10.00 & 2667 & -144 & -1118 & -161 & 1617 & 68 & -625 & -95 \\ 15.17 & 4081 & -155 & -7545 & -298 & 3008 & 141 & 46 & -70 \\ 19.99 & 5117 & -180 & -5482 & -268 & 4053 & 161 & 137 & -86 \\ 0.00 & 1251 & -88 & -386 & 150 & 482 & 131 & -108 & 19\end{array}$

Uniaxial State - y Direction $\left(\sigma_{x}=0\right)$ $\sigma_{x}, \sigma$

(MPa)

0.00

4.83

10.00

15.17

19.99

0
385
765
1123
1443

0
-107
-202
-288
-368

0
-1853
-2429
-2838
-3181

0
-114
-200
-279
-352

$\begin{array}{rr}0 & 0 \\ 202 & -48 \\ 499 & -117 \\ 815 & -183 \\ 1095 & -250\end{array}$

$\left(\sigma_{x}=\sigma_{y}\right)$

$\star 1,2,3,4=$ strain gage number (Figures 2.7 and 2.8 )

LAT = measured lateral strain

$A X=$ measured axial strain 


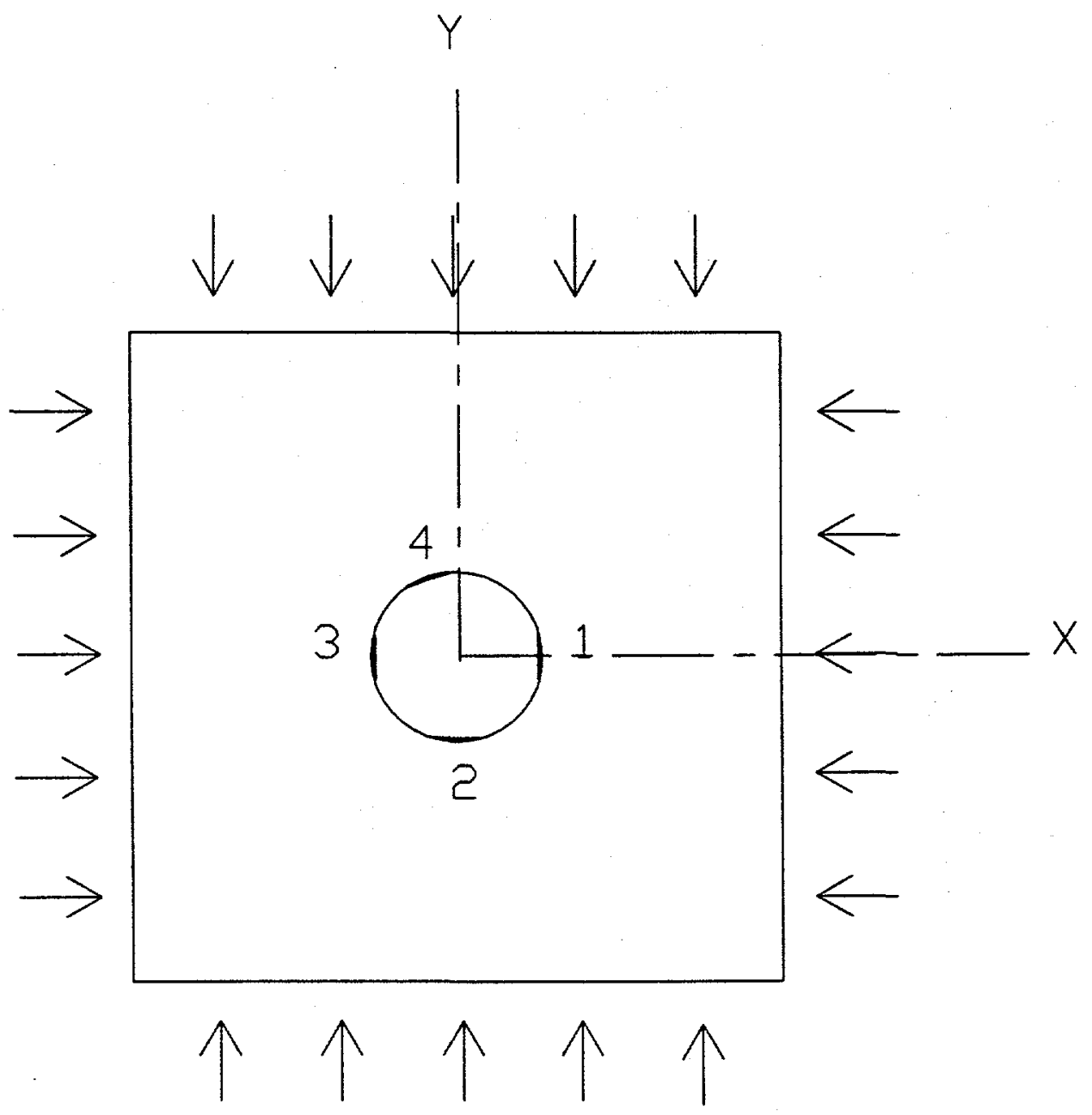

Figure 2.8 Orientation and location of strain gages $1,2,3$ and 4 with respect to loading direction ( $x$ and $y$ ). $100 \times 100 \times 200 \mathrm{~mm}$ tuff block with $25 \mathrm{~mm}$ diameter coaxial hole. 


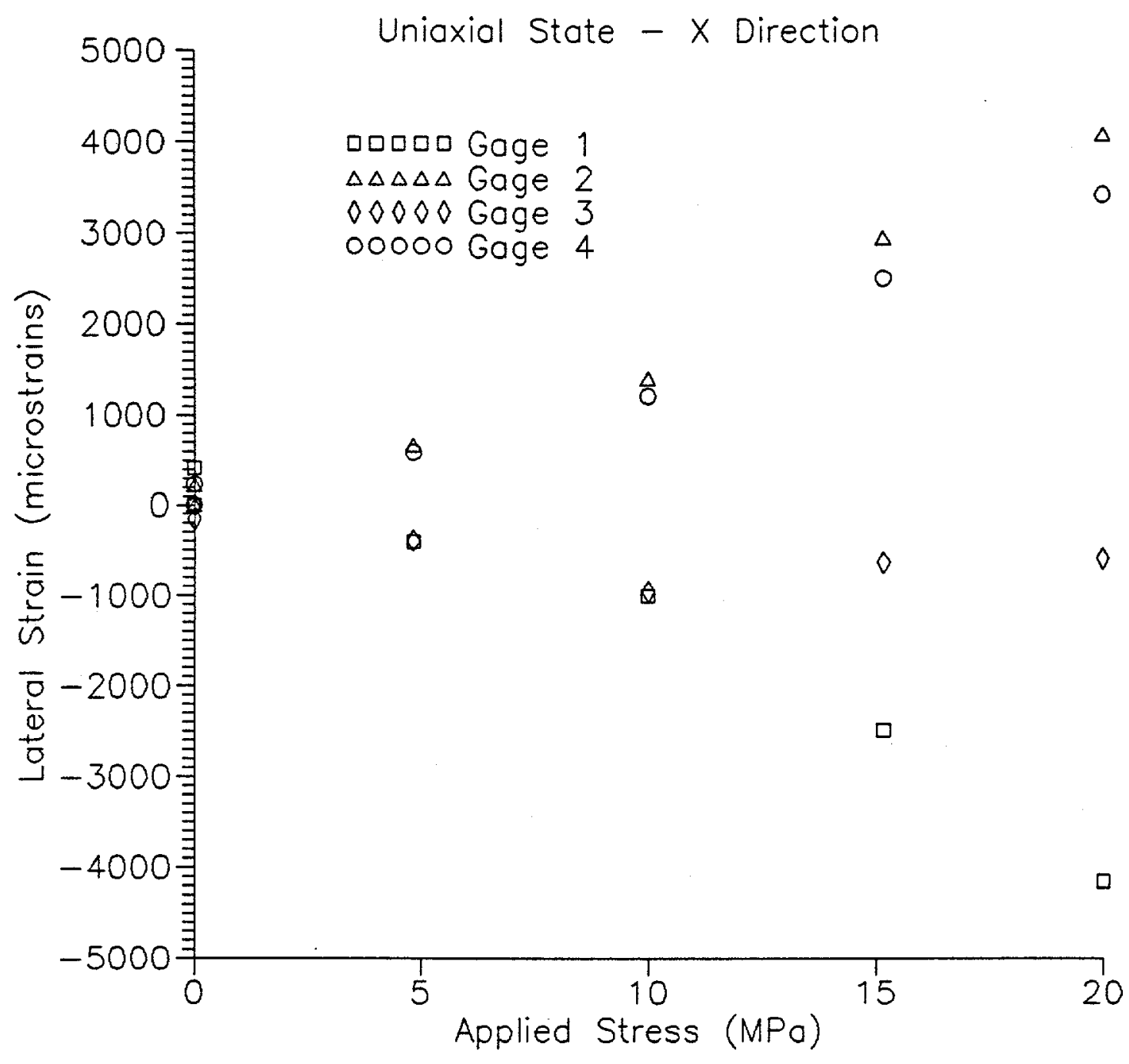

Figure 2.9 Results of sample TPS-PX1, $\sigma_{y}=0, \sigma_{x}$ increases from 0 to 20 $\mathrm{MPa}$. Borehole wall strains as a function of applied stress $\left(\sigma_{x}\right)$. 


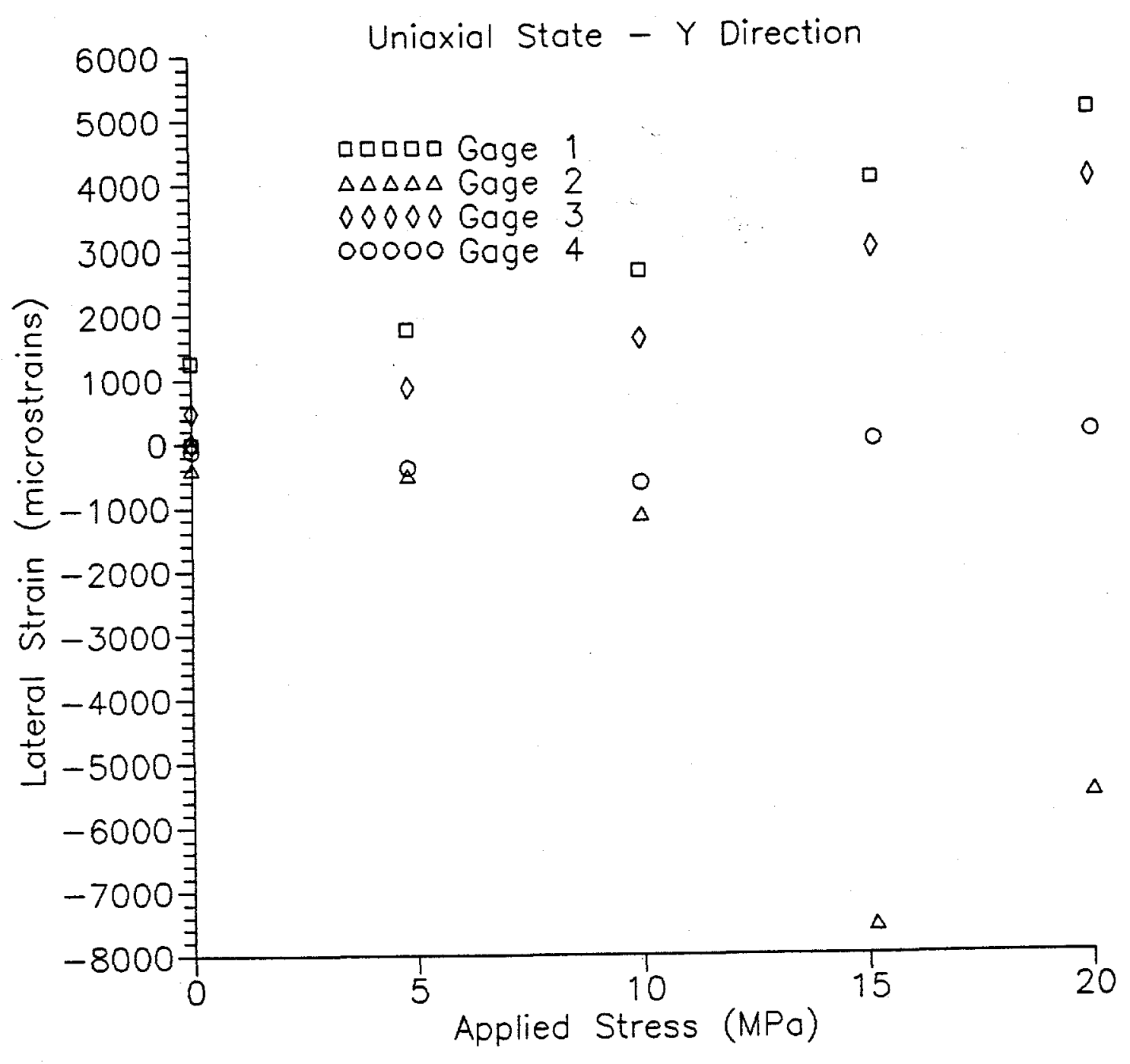

Figure 2.10 Results of sample TPS-PX1, $\sigma_{y}=0, \sigma_{y}$ increases from 0 to 20 $\mathrm{MPa}$. Borehole wall strains as a function of applied stress $\left(\sigma_{x}\right)$. 


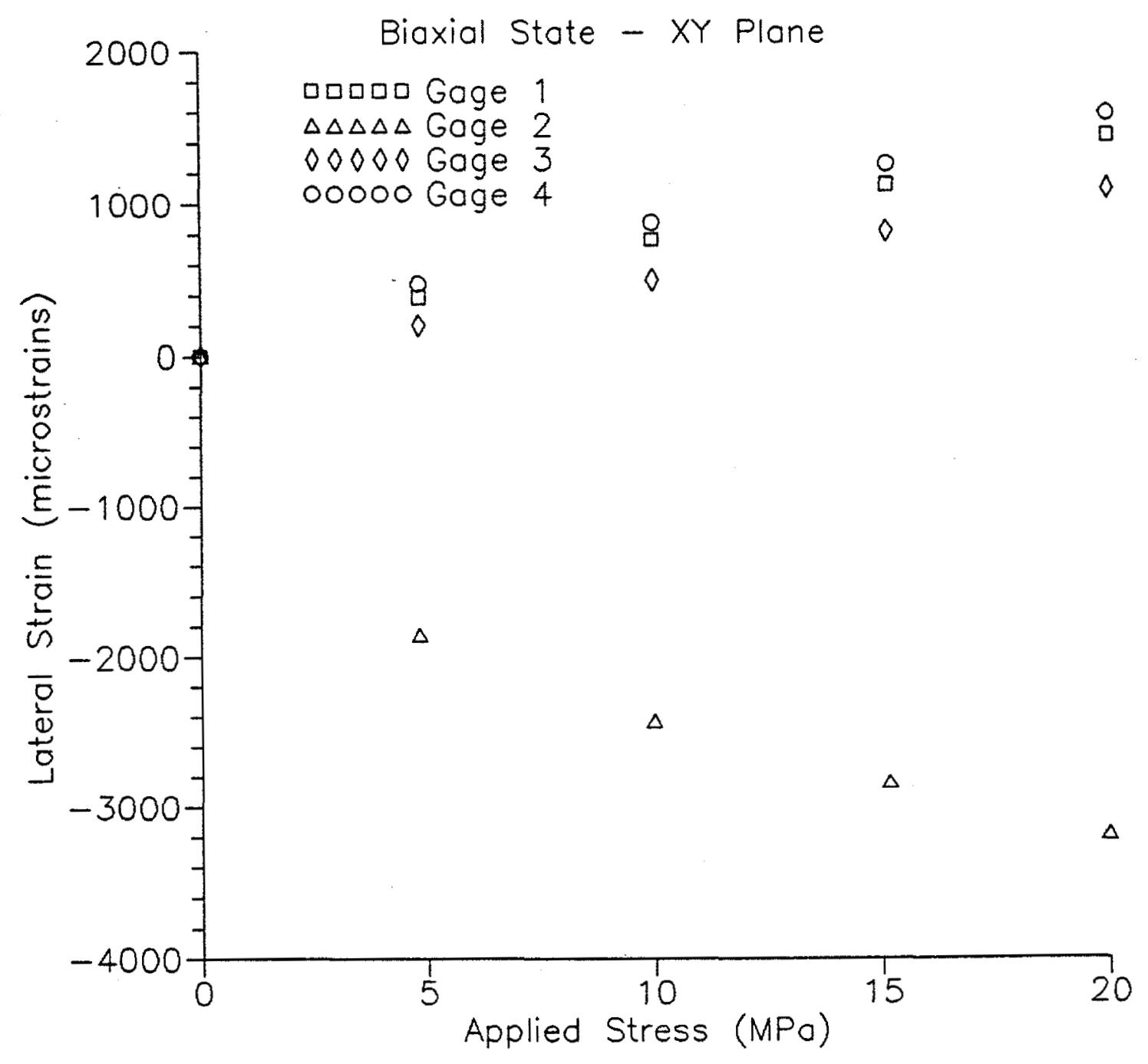

Figure 2.11 Uniform lateral stress $\left(\sigma_{x}=\sigma_{y}\right)$. Borehole wall strains as a function of applied stress. 
linear, which is different from the results obtained from the first two test series. This is probably due to the fact that the rock around the borehole has been consolidated by loading of the first two series.

The results from this biaxial borehole deformation and stability testing suggest that measurement of deformation by means of electrical resistance strain gages for this heterogeneous Topopah Spring tuff is not appropriate, in particular for small sample size. Fuenkajorn and Daemen (1991) recommend criteria to select sample sizes for heterogeneous rocks.

\subsection{Biaxial Borehole Stability Testing - Using the Lateral Load Frame}

\subsubsection{Test Method and Sample Preparation}

Due to the high strength of tuff samples, the load capacity of the triaxial and polyaxial cells (Sections 2.2 and 2.3) is not sufficient to induce a breakout around the borehole. A lateral load frame has been built to apply high boundary stresses to the samples. This method of borehole stability testing requires the load frames to apply a uniform stress. The loading directions are normal to the borehole axis. Appendix D gives the test procedure, configuration of the lateral load frame, and sample specifications. Rock samples are densely welded Apache Leap tuff. Each sample has been cut and ground to obtain a square plate with a circular hole at the center. The nominal dimensions are $20 \times 20 \times 5$ $\mathrm{cm}$ with a $2.5 \mathrm{~cm}$ diameter center hole. Figure 2,12 gives the dimensions of the test samples. All samples have flow layers normal to the hole axis. Sample preparation avoids visible cracks and fractures.

\subsubsection{Test Results}

\subsubsection{Sample AP60-1-BX2}

A horizontal stress of $7.0 \mathrm{MPa}$ is applied to the sample. An SBEL (CT500) load frame applies a vertical stress at a rate of approximately 6 MPa per minute. Figure 2.13 shows the applied stresses as a function of time. The horizontal stress is kept at $7.0 \mathrm{MPa}$ until the vertical stress reaches $3.85 \mathrm{MPa}$. After the vertical stress exceeds $3.85 \mathrm{MPa}$, the horizontal stress is increased at a rate of approximately $0.2 \mathrm{MPa}$ per minute. Borehole breakouts have been observed immediately after the vertical and horizontal stresses exceed 103.9 and $10.2 \mathrm{MPa}$, respectively. Small rock fragments with an average size of $1 \times 2 \times 3 \mathrm{~mm}$ chip out from the borehole wall along the horizontal diameter where the tangential compressive stresses concentrate. The breakouts continue as

the stresses increase. The vertical stress has been maintained at 121.2 MPa for about 3 minutes. During this period, chipping of the rock fragments stops. The depth of the breakouts is about 3 to $4 \mathrm{~mm}$. The breakout zone appears throughout the hole length and on both sides of the hole. The vertical stress is then increased to $129.1 \mathrm{MPa}$, which results in failure of the block sample. Splitting tensile fractures are induced nearly parallel to the loading plane, i.e. normal to the hole axis. 


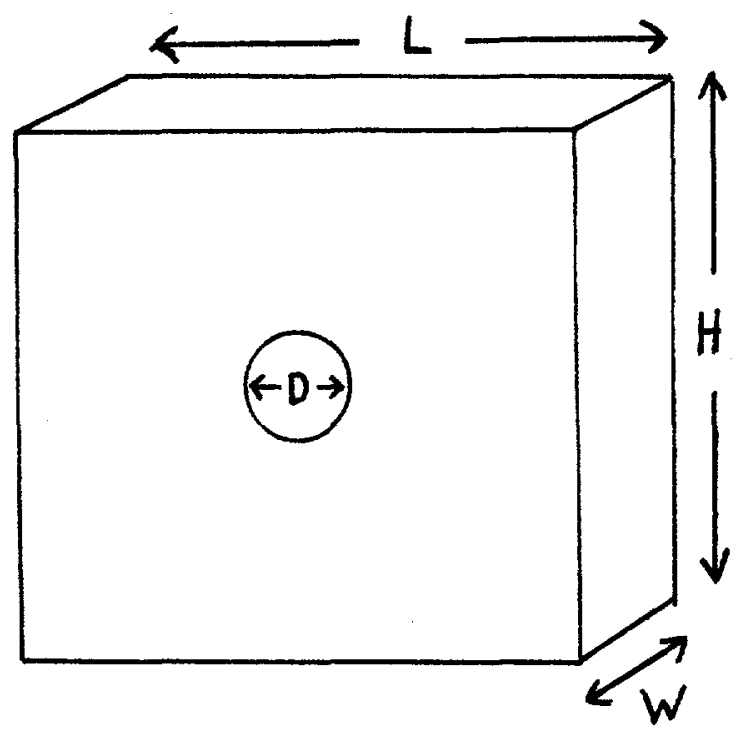

\begin{tabular}{|c|c|c|c|c|c|}
\hline $\begin{array}{c}\text { Sample } \\
\text { Number }\end{array}$ & $\begin{array}{c}\mathrm{D} \\
(\mathrm{cm})\end{array}$ & $\begin{array}{c}\mathrm{L} \\
(\mathrm{cm})\end{array}$ & $\begin{array}{c}\mathrm{H} \\
(\mathrm{cm})\end{array}$ & $\begin{array}{c}W \\
(\mathrm{~cm})\end{array}$ & $\begin{array}{c}\text { Density } \\
(\mathrm{g} / \mathrm{cc})\end{array}$ \\
\hline AP60-1-BX2 & 3.20 & 20.7 & 19.6 & 8.1 & 2.43 \\
\hline AP61-1-BX3 & 2.54 & 16.9 & 17.6 & 9.6 & 2.47 \\
\hline AP70-1-BS4 & 2.54 & 20.9 & 21.1 & 4.4 & 2.21 \\
\hline AP71-1-BS7 & 2.54 & 16.9 & 17.6 & 4.65 & 2.43 \\
\hline AP70-2-BS5 & 2.54 & 20.9 & 21.1 & 5.0 & 2.21 \\
\hline AP61-2-BS8 & 2.54 & 20.2 & 20.2 & 3.9 & 2.47 \\
\hline AP61-3-BS9 & 2.54 & 20.2 & 20.2 & 4.60 & 2.46 \\
\hline
\end{tabular}

Figure 2.12 Dimensions of biaxial borehole stability test samples. 


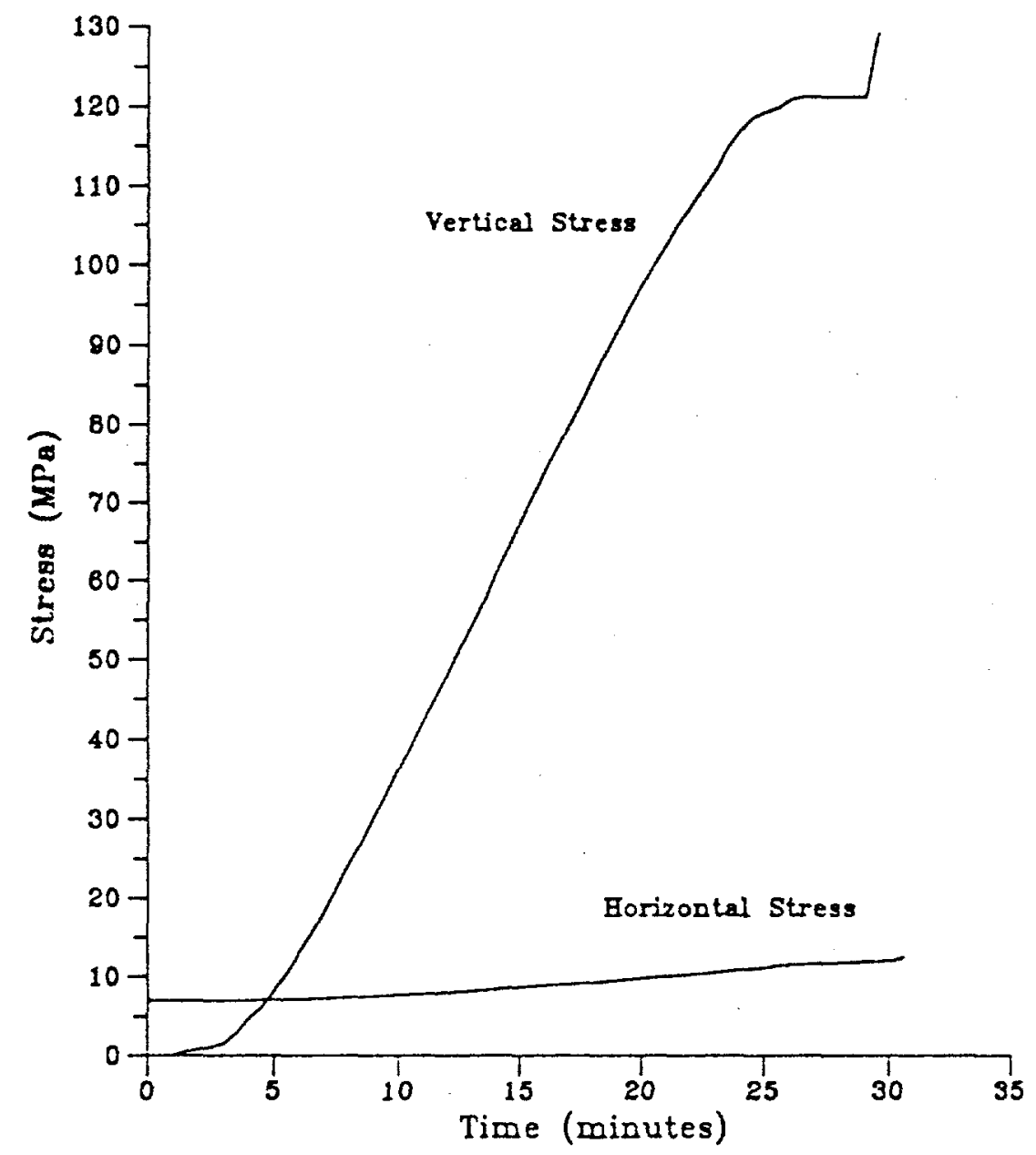

Figure 2.13 Applied stresses as a function of time for sample P60-1BX2. Sample collapses at a vertical stress of $129.1 \mathrm{MPa}$ and horizontal stress of $12.6 \mathrm{MPa}$. 
The compressive strength of sample AP60-1-BX2 is calculated by dividing the failure stress ( $129.1 \mathrm{MPa}$ ) by the minimum cross-sectional area (i.e. horizontal cross-section through the center of the hole). This results in a compressive strength of $153 \mathrm{MPa}$. The tangential compressive stress required to induce breakouts is calculated from the vertical and horizontal stresses applied immediately before the breakouts have been observed. The calculation uses elastic analysis and assumes that the borehole is in an infinite plate subjected to a biaxial stressfield (Obert and Duval1, 1967, pp 98-101). The solution yields a tangential compressive stress of $301 \mathrm{MPa}$. This stress is nearly twice the compressive strength of this block sample and is about four times larger than the uniaxial compressive strength obtained by using the ASTM (D2938) standard method (i.e. $73 \mathrm{MPa}$ - Fuenkajorn and Daemen, 1991). A similar discrepancy has been observed in borehole breakout experiments on different rock types by Daemen and Fairhurst (1971) and by Guenot (1987, 1989).

\subsubsection{Sample AP61-1-BX3}

Prior to applying a vertical stress, a horizontal stress of $6.58 \mathrm{MPa}$ is applied to sample AP61-1-BX3 (Figure 2.14). While the horizontal stress remains at $6.58 \mathrm{MPa}$, the vertical stress is increased from $0 \mathrm{MPa}$ at a rate of approximately $0.1 \mathrm{MPa}$ per minute. The sample has been loaded until the vertical and horizontal stresses reach 105.5 and $9.2 \mathrm{MPa}$, respectively. No chipping of rock fragments has been observed. Rapid unloading results in a sudden drop of the vertical stress from 105.5 to $0 \mathrm{MPa}$, and of the horizontal stress from 9.21 to $6.21 \mathrm{MPa}$. Examination of the sample after unloading using a magnifying glass reveals no breakouts. A hairline fracture parallel to the hole axis is found where the breakout is expected. The fracture shows no relative displacement. The remaining horizontal stress of $6.21 \mathrm{MPa}$ is about $6 \%$ lower than the stress applied initially $(6.58 \mathrm{MPa})$. This confirms that the applied vertical stress up to $105.5 \mathrm{MPa}$ may have induced some damage to the sample.

At the maximum vertical and horizontal stresses, elastic analysis gives the tangential compressive stress where the fracture is found as 307 $\mathrm{MPa}$. This stress is slightly higher than the breakout stress from sample AP60-1-BX2. The reason why no breakout is induced in sample AP61-1$B X 3$ probably is that sample $B X 2$ has a lower density than sample BX3, and hence has a lower strength (Fuenkajorn and Daemen, 1991). Experimental results by Kaiser and Maloney (1987) and numerical results by $\mathrm{Zheng}$ et al. (1988) show that the width and depth of breakouts increases as the stress rate increases.

\subsubsection{Sample AP70-1-BS4}

Sample AP70-1-BS4 has been subjected to a vertical uniaxial stress; the horizontal stress is kept at zero. This stress condition represents the most severe stress ratio (in the plane normal to hole axis) to which a borehole is subjected. Breakouts have been observed after the applied stress exceeds $43.5 \mathrm{MPa}$. The depth and width of the breakouts increase with increasing stress. The maximum depth and width observed at 101.6 $\mathrm{MPa}$ vertical stress are approximately 1.5 and $4 \mathrm{~mm}$. The block sample 


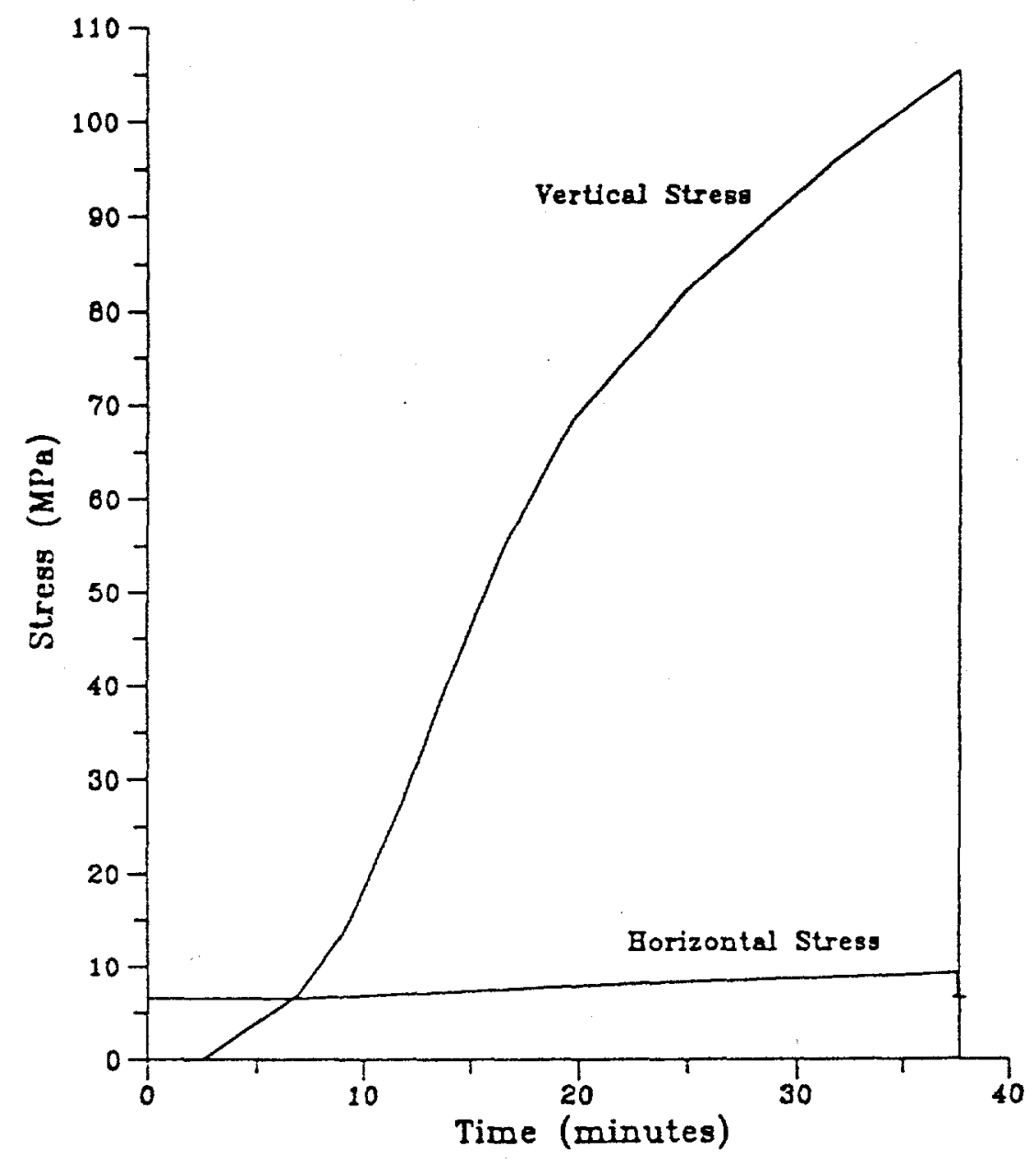

Figure 2.14 Applied vertical and horizontal stresses as a function of time for sample AP61-1-BX3. At the end of loading, vertical stress decreases rapidly from 105.5 to $0 \mathrm{MPa}$, and horizontal stress from 9.21 to $6.21 \mathrm{MPa}$. 
fails at this vertical stress. Elastic analysis calculates the tangential compressive stress required to induce breakouts at the borehole wall as $130.5 \mathrm{MPa}$.

\subsubsection{Sample AP71-1-BS7}

Similar to sample AP70-1-BS4, only vertical stresses are applied to sample AP71-1-BS7. Borehole breakouts have been observed after the vertical stress exceeds $104 \mathrm{MPa}$. The stress has been increased to $125.1 \mathrm{MPa}$ at which point the block sample fails. The maximum depth and width of the breakouts are 2.0 and $5.0 \mathrm{~mm}$. Elastic analysis calculates the tangential compressive stress required to induce breakouts as $312.3 \mathrm{MPa}$.

The stress required to induce breakouts for sample BS7 is higher than for sample BS4, because sample BS7 has a higher density than sample BS4. The stresses required to fail the two blocks are not that different. This agrees with a concept given by Fuenkajorn and Daemen (1991) that the effect of density variation on the rock strength is more pronounced on a small scale (in this case, the volume of the breakouts), than on a larger scale (in this case, the volume of the whole block).

\subsubsection{Sample AP70-2-BS5}

For sample AP70-2-BS5, borehole breakouts have been observed after the applied vertical stress exceeds $85.1 \mathrm{MPa}$, while the horizontal stress remains at $12.7 \mathrm{MPa}$. The tangential compressive stress at breakouts is calculated as $242.6 \mathrm{MPa}$. This stress is low compared to those of the other biaxial test samples tested under nonzero horizontal stress. This is probably because sample BS5 has the lowest density among these samples. The depth and width of the breakouts measured after unloading are about $2 \mathrm{~mm}$.

\subsubsection{Sample AP61-2-BS8}

Sample AP61-2-BS8 has failed along the flow layers before a breakout has been induced. Immediately before failure, vertical and horizontal stresses are 69.4 and $9.0 \mathrm{MPa}$. The failure plane is nearly normal to the hole axis. The sample density is relatively high compared to other samples. This sample is the only sample in which a borehole breakout has not been induced before the sample fails. This suggests that even though the tuff sample has a relatively high density (which implies a high strength), the flow layers can sometimes become a preferable failure plane, and hence the maximum stress that the rock around the borehole can sustain may not be as high as expected. The effect of the anisotropic strength of the Apache Leap tuff has not been quantitatively determined. Observations during sample preparation and on the post-test samples by Fuenkajorn and Daemen (1991) indicate that the flow layers in some Apache Leap tuff samples act as weakness planes. 


\subsubsection{Sample AP61-3-BS9}

Sample AP61-3-BS9 has been tested under a vertical to horizontal stress ratio of 0.29 . This ratio is the highest among all samples tested. Breakouts are observed in inclusions along the borehole wall when the vertical and horizontal stresses reach 209.3 and $60.3 \mathrm{MPa}$. The depth and width of the breakouts are less than $1 \mathrm{~mm}$. No breakouts develop in the tuff matrix (i.e. breakouts have not occurred throughout the hole length). This observation implies that even though the average strength of the heterogeneous rock is high, localized breakouts can occur in a borehole wall where low strength material is concentrated. The tangential compressive stress required to induce borehole breakouts for this sample is $567.6 \mathrm{MPa}$.

\subsubsection{Discussion}

Results from the biaxial borehole stability testing suggest that the density and the ratio of horizontal to vertical stresses applied in the plane normal to the hole axis significantly affect the borehole breakout stresses of the welded tuff. Figure 2.15 gives the tangential stresses at the breakout zone, calculated by elastic analysis, as a function of rock density. The number shown on each data point indicates the stress ratio when the breakouts occur. The breakout stress increases with density and with stress ratio. The effect of density on the tuff strength observed here agrees with Fuenkajorn and Daemen (1991) who conclude that the compressive strength of Apache Leap tuff increases 1inearly with density. In addition, the variation of strength with density decreases as the scale (i.e. sample size) increases.

The ratio of stresses in the plane normal to the hole axis affects the distribution of radial, tangential and axial stresses around the borehole, and, in particular, their gradients along the borehole circumference and away from it. The stress ratio changes the shape of the rock zone (i.e. breakout zone) subjected to a critical stress. This apparent enhancement of borehole strength due to an increase in ratio of minimum to maximum boundary stresses may not be entirely explainable by linear elastic analysis. The Apache Leap tuff may be a nonlinear material, in particular at high differential stresses and near failure.

Breakout stresses (i.e. the mechanical stability of the borehole) depend not only upon rock density, strength and stress ratio. Other factors need consideration before extrapolating these laboratory test results to in-situ conditions:

(1) Size effect. The compressive strength of rock around a small hole is likely to be higher than around a large one due to size effect. For the same stress ratio, breakouts of the larger hole may occur at a lower applied stress.

(2) Microfracturing. In this experiment, the vertical and horizontal stresses measured immediately before rock spalling represent the major and minor principal stresses (on the plane normal to the hole axis) required to induce breakouts. This does not necessarily mean that under smaller principal stresses, rock around the hole remains intact or free 


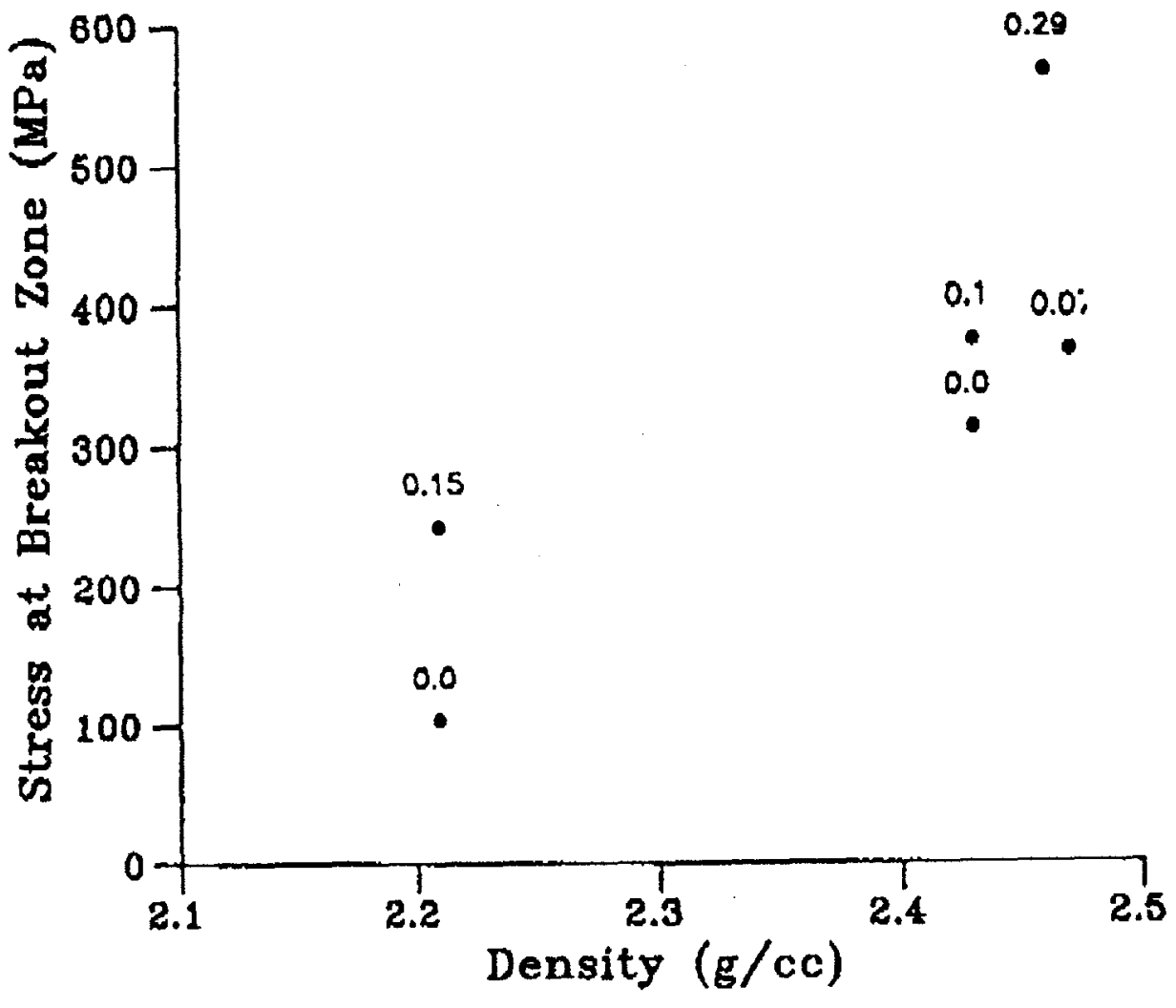

Figure 2.15 Tangential compressive stress at breakouts as a function of sample density. Results from biaxial borehole stability testing for various stress ratios $\left(\sigma_{H_{2}} / \sigma_{H}\right)$. Stress ratios are listed above each measurement result. 
of fractures. Some microcracks or fractures may have been induced before spalling has occurred. These cracks may not be detectable by visual observations (i.e. the cracks may not propagate to the hole wal1). Such cracks may develop along the hole length where the maximum tangential compressive stresses concentrate. The crack planes are likely parallel to the hole axis. For borehole sealing or plugging, these microfracture zones may provide a preferential flowpath bypasing a borehole plug.

(3) Time-dependent fracture propagation. The loading duration for the borehole stability testing is significantly shorter than that for insitu conditions. If fracture growth in tuff is time-dependent, the stress required for breakouts measured from the experiment may overestimate the minimum breakout stresses for the in-situ boreholes. Breakouts may occur at a lower stress if the borehole is subjected to that stress for a sufficiently long time. Time-dependent propagation of breakouts has been observed for some boreholes (Bell and Gough, 1982).

(4) Drilling-induced fractures. The drilling-induced fracture zone around a laboratory-prepared borehole is usually small and the fracture intensity is low, compared to those for in-situ boreholes (Fuenkajorn and Daemen, 1986). These fractures may create a low strength annulus adjacent to the borehole wall. The breakout stress obtained for laboratory drilled and small holes may overestimate those for in-situ boreholes.

\subsection{Strength of Boreholes in Apache Leap Tuff}

Regression analysis on the results from biaxial borehole stability test samples with densities between 2.43 and $2.47 \mathrm{~g} / \mathrm{cc}$ (Figure 2.15) indicates that the stress at breakouts increases exponentially with stress ratio:

$$
\sigma_{\theta f}=312.2 \exp \left(2.05 \sigma_{H 2} / \sigma_{H 1}\right)
$$

where $\sigma_{H_{2}}, \sigma_{H 1}=$ minimum and maximum applied boundary stresses

$\sigma_{\theta f}=$ tangential compressive stress at the borehole wall immediately before the breakout occurs (MPa).

$\sigma_{\theta f}$ is calculated using the linear elastic solution given by Obert and Duvall (1967, pp. 98-101). The regression for Eq. (2.5) gives a coefficient of correlation (R) of 0.997. Equation (2.5) can be generalized to predict the breakout stresses for a wider range of rock densities. Fuenkajorn and Daemen (1991) experimentally show that density is the main factor governing the variation of tuff strength (or, more generally, the mechanical heterogeneity of tuff). By assuming that the breakout stress $\left(\sigma_{0 f}\right)$ increases linearly with density, Eq. (2.5) can be rewritten as: 


$$
\sigma_{\theta f}=(949 \rho-1994) \exp \left(2.05 \sigma_{H 2} / \sigma_{H 1}\right)
$$

where $\rho=$ density of Apache Leap tuff $(\mathrm{g} / \mathrm{cc})$.

Equation (2.6) can be used to predict the strength of a borehole wall subjected to external biaxial stresses. However, the equation is valid for small boreholes $(2.5 \mathrm{~cm}$ diameter) only. It may overestimate the strength of the rock around large boreholes due to the size effect. Incorporation of the size effect into the above equation is not possible here due to the lack of test data on large boreholes. 
CHAPTER THREE

\section{CONCLUSIONS AND RECOMMENDATIONS FOR FUTURE RESEARCH}

\subsection{Conclusions}

The objective of this research is to determine experimentally the stability and deformation of a circular borehole in welded tuff subjected to various external boundary leads. The experimental work involves triaxial and biaxial borehole stability tests. Rock samples are densely welded Apache Leap tuff and Topopah Spring tuff. The nominal borehole diameter tested is $12.6 \mathrm{~mm}$ for triaxial stability testing, and $25.4 \mathrm{~mm}$ for biaxial borehole stability testing. The hole axis is parallel to one of the principal stress axes. The borehole has been drilled through the sample prior to applying the boundary stresses. The effect of borehole pressure is not studied. The boundary loads are progressively increased until breakouts occur or until the maximum capacity of the loading system is reached.

No borehole breakout has been observed during triaxial borehole stability testing. The Apache Leap tuff cylinders are subjected to uniform lateral and axial stresses up to $42 \mathrm{MPa}$. The boreholes tend to deform linearly with increasing applied stresses. Small permanent deformations (strains) are observed after unloading.

Three loading series of biaxial borehole stability testing on a Topopah Spring tuff sample have been performed using a polyaxial cell. The maximum boundary stresses are up to $20 \mathrm{MPa}$. No borehole breakouts have been observed. The sample has been subjected to uniaxial lateral stresses for the first two test series and to uniform lateral stresses for the last test series. Inconsistency of the strain results has been observed among the three test series. Probable causes of the inconsistencies are poor strain gage bonding, heterogeneity and inelasticity of the tuff, and separation of pre-existing microcracks or development of microcracks near the borehole wall when it is subjected to tangential tensile stress during uniaxial loading.

Biaxial borehole stability tests have been performed, using a lateral load frame, on seven Apache Leap tuff samples. The ratio of applied minimum to maximum boundary stresses varies from 0 to 0.29 . Results indicate that rock density and stress ratio significantly affect the breakout stresses. The breakout stress is the tangential compressive stress at the borehole wall where breakouts are induced. Elastic analysis is used in the calculation of this stress. The breakout stresses vary from $130 \mathrm{MPa}$ for a sample with a density of $2.21 \mathrm{~g} / \mathrm{cc}$ and a stress ratio of 0 , to $568 \mathrm{MPa}$ for a sample with a density of $2.46 \mathrm{~g} / \mathrm{cc}$ and a stress ratio of 0.29 . This stress range is much higher than the compressive strength of the tuff, determined by uniaxial compression testing. The increase in breakout stress with density and stress ratio may be represented by the empirical equation: 


$$
\begin{gathered}
\sigma_{\theta f}=(949 \rho-1994) \exp \left(2.05 \sigma_{H 2} / \sigma_{H 1}\right) \\
(\text { with } \rho \text { in } \mathrm{g} / \mathrm{cc})
\end{gathered}
$$

The depth and width of borehole breakouts are small and usually do not exceed a few millimeters.

The variation of borehole strength with stress ratio could be due to the fact that the shape and size of the rock subjected to critical stresses in the breakout zones changes with stress ratio. This explanation relates to the effect of size and stress gradient on rock strength (Jaeger and Cook, 1979, pp. 195-207).

The results from biaxial testing suggest that Apache Leap tuff is highly heterogeneous. Correction for the strength variation due to nonuniformity of the rock by considering the bulk density seems adequate. Nevertheless, the bulk density of a tuff block may not represent the density of the small volume of the rock in the breakout zone. This argument is supported by experimental evidence that the breakouts occur only in the soft inclusions, while the stronger rock matrix surrounding them remains intact. Flow layers in some Apache Leap tuff samples appear as weakness planes. These weakness planes significantly reduce the strength of the rock sample. Hence the strength of the rock around a borehole may not be as high as predicted by analyses that do not account for the effects of flow layers.

\subsection{Recommendations for Future Research}

It would be desirable to repeat virtually all types of tests reported on here with more extensive instrumentation. For example, redundant strain gages on the borehole walls of the tests may resolve the anomalous strain results in the biaxial borehole testing (Section 2.3). Strain gages may not be the best or even a very desirable strain monitoring system on highly heterogeneous tuffs. Complementary measurements, e.g. continuous or many-point borehole convergence measures, would be useful.

More biaxial borehole stability testing should be performed. The stress ratio $\left(\sigma_{H 2} / \sigma_{H 1}\right)$ should be varied from 0 to 1 . The tests should be conducted for a wide range of tuff densities. Various hole sizes should be tested to investigate the size effect. The minimum test hole diameter should be up to 15 or $20 \mathrm{~cm}$. To prevent tensile splitting along the loading plane for a high stress ratio testing, the block specimen should be confined in the axial direction. The axial load should be monitored during the test so that the breakouts can be analyzed in three dimensions.

Microscopic examinations (i.e. petrographic, scanning electron microscopies) should be performed to study the pattern and propagation of cracks within and beyond the breakout zones. Acoustic emission may be used to detect the crack initiation during the test. 
Nonlinear elastic or elastoplastic analysis may be required to describe the actual behavior of the rock before and after breakouts occur. Fracture mechanics may help explain the development and pattern of cracks in the breakout zone, More generally, the numerous recently published analysis methods of borehole stability and breakouts should be integrated with the experimental work.

Although the results reported here suggest that simple isotropic linearly elastic modeling may adequately describe the behavior of the welded tuff tested, sufficient uncertainty remains to warrant further validation efforts.

of most interest from a sealing performance point of view is the risk of developing bypass flow around a seal as a result of fracturing of the host rock. Major remaining uncertainties concern the influence of size and of long-term (i.e. permanent) loading. Embedded in the size effect concern is the high probability that flow layer effects may weaken larger samples than tested here (even aside from other effects, notably the influence of joints).

Experimental evidence has indicated that flow layers in tuff sometimes act as weakness planes. The effect of the flow layers on borehole stability can be investigated by varying the test hole orientation with respect to the flow layers. 


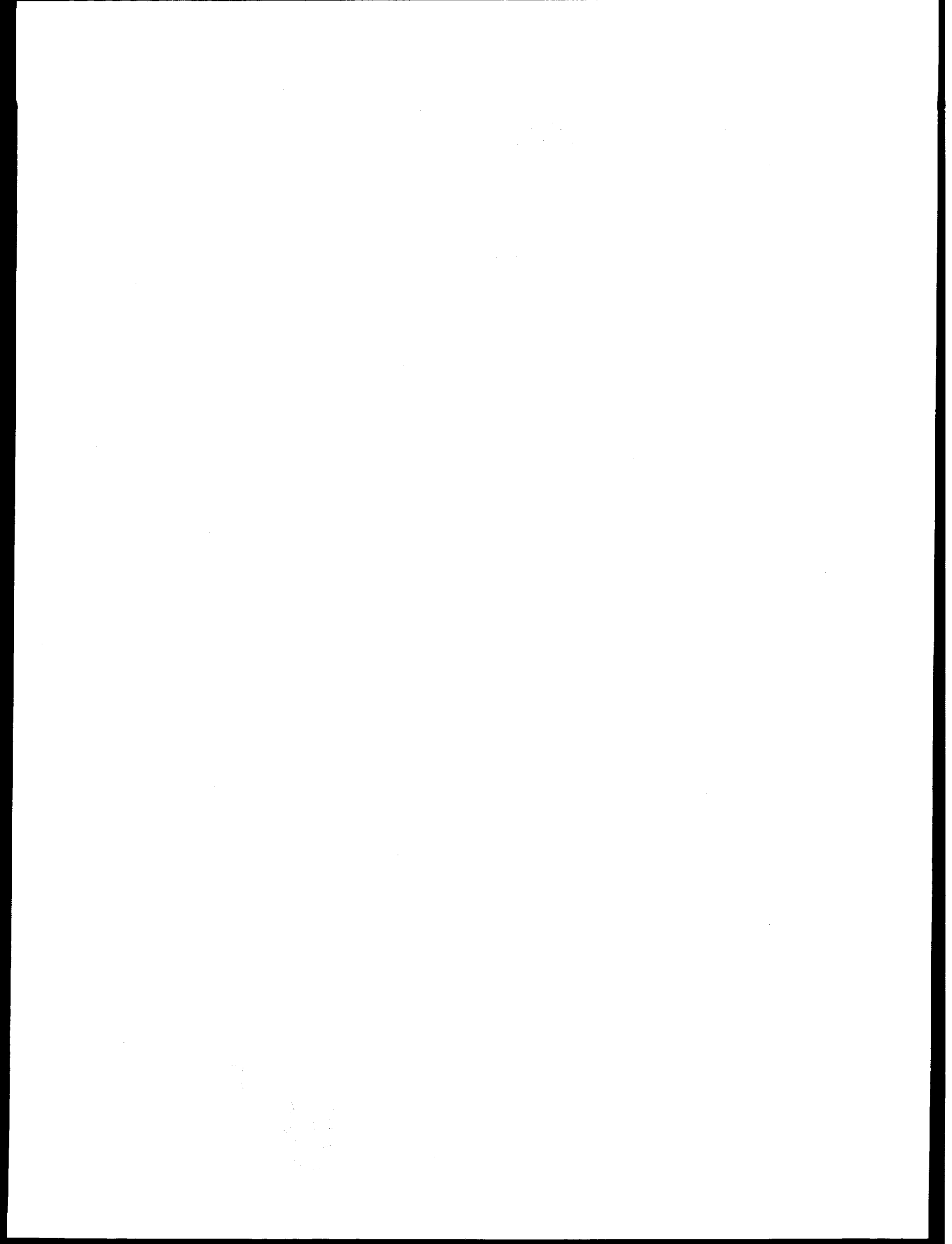




\section{REFERENCES}

Akgun, H. and J.J.K. Daemen, 1986, "Size Influence on the Sealing Performance of Cementitious Borehole Plugs," Technical Report, NUREG/CR-4738, prepared for the U.S. Nuclear Regulatory Commission, Office of Nuclear Regulatory Research, Division of Engineering Safety, by the Department of Mining and Geological Engineering, University of Arizona, Tucson.

Anderson, R.N., R.H. Morin, R.L. Newmark, and C.A. Barton, 1989, "Thermal Stresses and Borehole Stability at DSDP Hole 504B, Eastern Equatorial Pacific," Transactions of the American Geophysical Union, April 11, Vol. 70, No. 15, p. 470.

Bandis, S.C. and N. Barton, 1986, "Failure Modes of Deep Boreholes," Proc., 27th U.S. Symp. on Rock Mech., Univ. of Alabama, Tuscaloosa, June 23-25, H.L. Hartman, ed., Society of Mining Engineers, Inc., Littleton, CO, pp. 599-605.

Bell, J.S. and D.I. Gough, 1982, "The Use of Borehole Breakouts in the Study of Crustal Stress," Proc. of Workshop XVII, on Hydraulic Fracturing Stress Measurements, Dec. 2-5, 1981, Vo1. II, pp. 539-557, U.S.G.S. Open-File Report 82-1075, Menlo, CA.

Beus, M.J. and S.S.M. Chan, 1982, "Structural Design for Deep Shafts in Hard Rocks," pp. 65-78, Premining Investigations for Hardrock Mines, Proceedings: Bureau of Mines Technology Transfer Seminar, Denver, CO, Sept. 25, 1981, USBM Info. Circular 8891.

Bieniawski, Z.T. and J. Bauer, 1982, Discussion, J. Geotech. Engrg. Div., Am. Soc. Civil Engrs., Vol. 108, pp. 670-672.

Biot, M.A., 1974, "Exact Simplified Non-Linear Stress and Fracture Analysis around Cavities in Rock," Inter. J. of Rock Mech. and Mining Sciences \& Geomechanics Abstracts, Vol. 11, No. 7, pp. 261-266, Pergamon Press, Great Britain.

Black, R.A.L. and A.M. Starfield, 1964, "A Dynamic or Energy Approach to Strata Control Theory and Practice," pp. 450-467, Proc., 4th Intern. Conf. on Strata Control and Rock Mechanics, Henry Krumb School of Mines, Columbia University, New York, May.

Cheatham, J.B., Jr., Y.H. Lin, and P.D. Pattillo, 1986, "Analysis of Borehole Stability Using a Strain Softening Mode1," Proc., 27th U.S. Symp. on Rock Mech., Univ. of Alabama, Tuscaloosa, June 23-25, H.L. Hartman, ed., Society of Mining Engineers, Inc, Littleton, CO, pP. 552-561.

Costin, L.S., 1987, "Time-Dependent Deformation and Failure," Ch. 5, pp. 167-215 in Fracture Mechanics of Rock, B.K. Atkinson, ed., Academic Press, London, 543 pp. 
Daemen, J.J.K. and C. Fairhurst, 1971, "Influence of Failed Rock Properties on Tunnel Stability," Proc., 12th U.S. Symp. on Rock Mech., Univ. of Missouri-Rolla, G.B. Clark, ed., pp. 855-875, pub. by AIME, New York.

Daemen, J.J.K., W.B. Greer, K. Fuenkajorn, A. Yazdandoost, H. Akgun, A. Schaffer, A.F. Kimbrell, T.S. Avery, J.R. Williams, B. Kousari, and R.O. Roko, 1986, "Experimental Assessment of Borehole Plug Performance," NUREG/CR-4642, prepared for the U.S. Nuclear Regulatory Commission, Office of Nuclear Regulatory Research, by the Department of Mining and Geological Engineering, University of Arizona, Tucson.

Detournay, E., 1986, "Elastoplastic Model of a Deep Tunnel for a Rock with Variable Dilatancy," Rock Mechanics and Rock Engineering, Vol. 19, Springer-Verlag, New York, pp. 99-108.

Detournay, E. and C. Fairhurst, 1987, "Two-Dimensional Elastoplastic Analysis of a Long, Cylindrical Cavity Under Nonhydrostatic Loading," Rock Mechanics and Rock Engineering, Int1. J. Rock Mech. Min. Sci. \& Geomech. Abstr., Vol. 24, no. 4, Pergamon Pressg, Oxford, England, pp. 197-211.

Detournay, E. and C.M. St. John, 1988, "Design Charts for a Deep Circular Tunnel Under Non-Uniform Loading," Rock Mechanics and Rock Engineering, Vol. 21, Springer-Verlag, New York, pp. 119-137.

Dhar, B.B., B.S. Verma, and S. Ratan, 1979, "Fracture Growth Around Openings in Rock Models and Their Effect on the Design of Stable Openings," Proc., 4th Inter. Cong. on Rock Mech., Vol. 2, pp. 99-104, A.A. Balkema, Rotterdam.

Ewy, R.T., N.G.W. Cook, and L.R. Myer, 1988, "Hollow Cylinder Tests for Studying Fracture Around Underground Openings," Proc., 29th U.S. Symp. on Rock Mech., June 13-15, Univ. of Minnesota, Minneapolis, Cundall et al., eds., A.A. Balkema, Rotterdam, pp. 67-74.

Fuenkajorn, K. and J.J.K. Daemen, 1986, "Experimental Assessment of Borehole Wall Drilling Damage in Basaltic Rocks," Technical Report, NUREG/CR-4641, prepared for the U.S. Nuclear Regulatory Commission, by the Department of Mining and Geological Engineering, University of Arizona, Tucson.

Fuenkajorn, K. and J.J.K. Daemen, 1991, "Mechanical Characterization of the Densely Welded Apache Leap Tuff," Technical Report, NUREG/CR5688, prepared for the U.S. Nuclear Regulatory Commission, by the Department of Mining and Geological Engineering, University of Arizona, Tucson.

Gay, N.C., 1973, "Fracture Growth Around Openings in Thick-Walled Cylinders of Rock Subjected to Hydrostatic Compression," Int. J. Rock Mech. Min. Sci. \& Geomech. Abstracts, Vol. 10, No. 1, pp. 209-233, Pergamon Press, Great Britain. 
Gay, N.C., 1976, "Fracture Growth Around Openings in Large Blocks of Rock Subjected to Uniaxial and Biaxial Compression," Int. J. Rock Mech. Min. Sci. \& Geomech. Abstracts, Vol. 13, No. 8, pp. 231-243, Pergamon Press, Great Britain.

Gough, D.I. and J.S. Bell, 1982, "Stress Orientations from Borehole Wall Fractures with Examples from Colorado, East Texas, and Northern Canada," Can. J. of Earth Sci., Vol. 19, pp. 1358-1370.

Gramberg, J., 1965, "Axial Cleavage Fracturing, A Significant Process in Mining and Geology," Engineering Geology, Vo1. 1, No. 1, Pp. 31-72, Elsevier Pub. Co., Amsterdam.

Guenot, A., 1987, "Contraintes et ruptures autour des forages petroliers (Stress and rupture conditions around oil wellbores), "Proc. 6th Inter. Cong. on Rock Mechanics, Montreal, Vol. 1, pp. 109-118, Balkema, Boston.

Guenot, A., 1989, "Borehole Breakouts and Stress Fields," Inter. J. of Rock Mech. and Mining Sci. \& Geomech., Abstracts, Vol. 26, No. 3, Pergamon Press, Great Britain, pp. 185-195.

Guenot, A. and F.J. Santare111, 1988, "Borehole Stability: A New Challenge for an 01d Problem," Proc., 29th U.S. Symp. on Rock Mech., June 13-15, Univ. of Minnesota, Minneapolis, Cundall et al, eds., A.A. Balkema, Rotterdam, pp. 453-460.

Haimson, B.C. and C.G. Herrick, 1985, "In Situ Stress Evaluation from Borehole Breakouts: Experimental Studies," Research and Engineering Applications in Rock Masses, E. Ashworth, ed., Proc., 26th U.S. Symp. on Rock Mech., June 26-29, Rapid City, SD, A.A. Balkema, Rotterdam, pp. 1207-1218.

Heuer, R.E. and A.J. Hendron, Jr., 1971, "Geomechanics Model Study of the Behavior of Underground Openings in Rock Subjected to Static Loads," Contract Report N-69-1, by Dept. of Civil Engrg., University of Illinois, for U.S. Army Corps of Engineers Waterways Experiment Station, Vicksburg, MS, Feb.

Hoek, E., 1964, "Rock Fracture Around Mining Excavations," pp. 334-348, Proc., 4th Intern. Conf. on Strata Control and Rock Mechanics, Henry Krumb School of Mines, Columbia University, New York, May.

Hoek, E., 1965, "Rock Fracture Under Static Stress Conditions," Nat. Mech. Engrg. Res. Inst. Report MEG 383, CSIR, S. Africa, 200 pp.

Hoek, E. and E.T. Brown, 1980, Underground Excavations in Rock, The Institution of Mining Metallurgy, London.

Horii, H. and S. Nemat-Nasser, 1985, "Compression-Induced Microcrack Growth in Brittle Solids: Axial Splitting and Shear Failure," J. of Geophys. Res., Am. Geophys. Union, Vol. 90, No. B4, pp. 3105-3125. 
Isaacson, E. de St. Q., 1958, Rock Pressure in Mines, Mining Publications, Ltd., London, $\mathrm{x}+212 \mathrm{pp}$.

Jaeger, J.C., 1969, Elasticity, Fracture and Flow - With Engineering and Geological Applications, 3rd Ed., viii + 268 pp., Methuen \& Co., Ltd., and Science Paperbacks, 1969.

Jaeger, J.C. and N.G.W. Cook, 1979, Fundamentals of Rock Mechanics, Third Edition, Chapman and Hall, London, John Wiley and Sons, Inc., New York.

Juhlin, C. and H. Sandstedt, 1989, "Storage of Nuclear Waste in Very Deep Boreholes: Feasibility Study and Assessment of Economic Potential," Technical Report SKB 89-39, prepared for Svensk Karnbranslehantering, $\mathrm{Ab}$, Swedish Nuclear Fuel and Waste Management Co., Stockholm, by Vattenfall, Dep. Bel.

Kaiser, P.K., A. Guenot, and N.R. Morgenstern, 1985, "Deformation of Small Tunnels - IV. Behavior During Failure," Int. J. of Rock Mech. and Mining Sciences \& Geomech. Abstracts, Vol. 22, No. 3, pp. 141-152, Pergamon Press Ltd., Great Britain.

Kaiser, P.K. and A. Kwong, 1988, "Stability of Openings in Rock Imperfections," Proc., 29th U.S. Symp. on Rock Mech., June 13-15, Univ. of Minnesota, Minneapolis, Cundall et al., eds., A.A. Balkema, Rotterdam, pp. 735-738.

Kaiser, P.K. and S. Maloney, 1987, "Factors Influencing the Stability of Deep Boreholes," Proc. of the 6th Cong. on Rock Mechanics, Vol. 1 , Montreal, pp. 675-680, A.A. Balkema, Boston.

Kastner, H., 1971, Statik des Tunnel- und Stollenbaues, Springer-Verlag, Berlin.

Kozlovsky, Ye.A., 1984, "The World's Deepest We11," pp. 98-104, Scientific American, Vol. 251, No. 6, Dec.

Kranz, R.L., 1979, "Crack-Crack and Crack-Pore Interactions in Stressed Granite," Int. J. of Rock Mech. and Mining Sciences \& Geomech. Abstracts, Vol. 16, pp. 37-47, Pergamon Press Ltd., Great Britain.

Kranz, R.L., 1983, "Microcracks in Rocks: A Review," Tectonophysics, Vol. 100, pp. 449-480, Elsevier Science Pub. B.V., Amsterdam.

Leeman, E.R., 1965, "The Measurement of Stress in Rock - Part I - The Principles of Rock Stress Measurements," pp. 248-284, Symp. on Rock Mechanics and Strata Control in Mines, Johannesburg, April 1963 June 1965. The South African Institute of Mining and Metallurgy, Johannesburg.

Maloney, S.M. and P.K. Kaiser, 1985, "Detection of Yield and Rupture of Underground Openings by Displacement Monitoring," Proc., 26th U.S. Symp. on Rock Mech., June 26-28, Rapid City, SD, A.A. Balkema, Rottterdam, pp. 957-966. 
Mastin, L., 1988, "Effect of Borehole Deviation on Breakout Orientations," J. of Geophys. Res., Am. Geophys. Union, Vol. 93, No. B8, pp. 9187-9195.

Maury, V., 1987, "Observations, recherches et resultats recents sur les mecanismes de ruptures autour de galeries isolees (Observations, researches and recent results about failure mechanisms around single galleries), " Proc., 6th Inter. Cong. on Rock Mech., Vol. 2, Montrea1, Inter. Soc. of Rock Mech., pp. 1119-1128.

Neretnieks, I., 1987, "Some Coupled Processes Which May Be Important for a Nuclear Waste Repository," Ch. 55, pp. 759-763, Coupled Processes Associated with Nuclear Waste Repositories, C.-F. Tsang, ed., Academic Press, Inc., Orlando.

Obert, L. and W.I. Duval1, 1967, Rock Mechanics and the Design of Structures in Rock, John Wiley \& Sons, Inc., New York.

Onaisi, A., J.P. Sarda and M. Bouteca, 1990, "Experimenta1 and Theoretical Investigation of Borehole Breakouts," Rock Mechanics: Contributions and Challenges, W.A. Hustrulid and G.A. Johnson, eds., Colorado School of Mines, Golden, June 18-20, A.A. Balkema, Rotterdam, Netherlands, pp. 703-710.

Rabcewicz, L.v., 1964-65, "The New Austrian Tunnelling Method," Water Power, Vol. 16, pp. 453-457 (Nov.), pp. 511-515 (Dec.), and Vol. 17 , pp. 19-24 (Jan.)

Richardson, A., 1990, "Preliminary Shaft Liner Design Criteria and Methodology Guide," Technical Report SAND88-7060, prepared for the U.S. Dept. of Energy, by Sandia Natl. Laboratories, Albuquerque, NM, April.

St. John, C.M., E. Detournay, and C. Fairhurst, 1984, "Design Chart for a Deep Circular Tunnel Under Non-Hydrostatic Loading," Rock Mechanics in Productivity and Protection, Proc. 25th Symp. Rock Mech., Northwestern Univ., Evanston, IL, pp. 849-856.

Santare11i, F.J. and E.T. Brown, 1987, "Performance of Deep Wellbores in Rock with a Confining Pressure-Dependent Elastic Modulus," Proc., 6 th Int. Cong. on Rock Mechanics, Montreal, Vol. 2, pp. 1217-1222, A.A. Balkema, Rotterdam.

Santarelli, F.J., E.T. Brown, and V. Maury, 1986, "Analysis of Borehole Stresses Using Pressure-Dependent, Linear Elasticity," Technical Note, Inter. J. of Rock Mech. and Mining Sci. \& Geomech. Abstracts, Vol. 23, No. 6, pp. 445-449, Pergamon Journal Ltd., Great Britain.

Sperry, P.E. and R.E. Heuer, 1972, "Excavation and Support of Navajo Tunnel No. 3," Ch. 22, pp. 539-572, Vo1. 1, Proc., N. American. Rapid Excavation and Tunneling Conf., Chicago, June. 
South, D.L. and J.J.K. Daemen, 1986, "Permeameter Studies of Water Flow Through Cement and Clay Borehole Seals in Granite, Basalt and Tuff," Technical Report, NUREG/CR-4748, prepared for the U.S. Nuclear Regulatory Commission, by the Department of Mining and Geological Engineering, University of Arizona, Tucson.

Stacey, T.R. and C.L. de Jongh, 1977, "Stress Fracturing Around a DeepLevel Bored Tunnel," J. of the S. African Inst. of Mining and Metall., Vol. 78, No. 5, pp. 124-133.

Teufe1, L.W., 1985, "Insights into the Relationship Between Wellbore Breakouts, Natural Fractures, and In Situ Stress," pp. 1199-1206, Research and Engineering Applications in Rock Masses, E. Ashworth, ed., Proc. 26th U.S. Symp. on Rock Mechanics, Rapid City, SD, June. A.A. Balkema, Rotterdam.

Turchaninov, I.A., M.A. Iofis, and E.V. Kasparyan, 1979, Principles of Rock Mechanics, Translation ed. by W.A. Hustrulid, from Russian by A.L. Peabody, pub. by Terraspace, Inc., Maryland.

Wang, F.D., L.A. Panek and M.C. Sun, 1971, "Stability Analysis of Underground Openings Using a Coulomb Failure Criterion," pp. 317-321, Transactions, Soc. of Mining Engineers of AIME, Vol. 250, Dec.

Zheng, Z., N.G.W. Cook, and L.R. Myer, 1988, "Borehole Breakout and Stress Measurements, Proc., 29th U.S. Symp. on Rock Mech., June 13-15, Univ. of Minnesota, Minneapolis, Cundall et al., eds., A.A. Balkema, Rotterdam, pp. 471-478.

Zoback, M.D. and J.H. Healy, 1989, "Overview of In-Situ Stress Measurements in the Cajon Pass Scientific Drillhole to a Depth of $3.5 \mathrm{~km}$, "Transactions of the Am. Geophy. Union, April 11, Vol. 70, No. 15, p. 480 .

Zoback, M.D., D. Moos, L. Mastin, and R.N. Anderson, 1985, "Well Bore Breakouts and In Situ Stress," J. of Geophy. Res., Vol. 90, No. B7, PP. 5523-30. 


\section{APPENDIX A \\ PROCEDURE FOR \\ TRIAXIAL BOREHOLE DEFORMATION AND STABILITY TESTS}

\section{A.1 Objective}

The purpose of this test procedure is to determine the deformation and stability of a borehole in an intact rock sample subjected to triaxial loading. The deformation and stability of the borehole are measured as a function of differential stresses and confining pressures.

\section{A.2 Apparatus}

- triaxial cell ( 10,000 psi capacity)

- loading frame (SBEL CT-500)

- servo controller (SBEL 447)

- Enerpac EH-80 hydraulic hand pump

- pressure gage

- strain gages (Micro-Measurement: WA-06-500WT-120)

- strain indicator with switch balance unit

- digital thermometer and thermocouple

- heat shrink tube and heat gun

- hydraulic oil reservoir

- air and oil lines

- linear voltage displacement transducer (LVDT)

- load cell

\section{A. 3 Sample Specifications}

The test specimen measures $51 \mathrm{~mm}$ outside diameter, $13 \mathrm{~mm}$ inside diameter, and $127 \mathrm{~mm}$ length. End surfaces of the cylinder are ground flat and parallel. The perpendicularity and parallelism should be within $0.5^{\circ}$. Eccentricity of the center hole should be kept minimal.

Determination of the smoothness, perpendicularity, parallelism, and dimensions of the sample follows ASTM methods D2938, Section 4, and D2664, Section 6 .

\section{A. 4 Test Procedure}

The method to apply the confining pressure and axial load to the rock cylinder is similar to the method for determining the triaxial compressive strength of intact rock (ASTM D2664; Vogler and Kovari, 1977).

\section{A.4.1 Installation of Strain Gages}

Electrical resistance strain gages are installed at the midsection of the borehole. Surface preparation and installation procedure are given by Measurements Group, Inc. (1983) and Mordan (1983). The strain gages measure the circumferential and axial deformation of the borehole wall. 


\section{A.4.2 Method to Install Rock Sample in Triaxial Cell}

A) Remove upper ram from cell and stand upside down on counter.

B) Place sample on ram, with the top of the sample facing down.

C) Put platen with o-rings on top of sample. Use platen with the same diameter as, or slightly larger than, that of the specimen. Insert the gage wires through the pore pressure port.

D) Cut heat shrink tubing so that it covers the sample and extends just past both end platens.

E) Use heat gun to seal tubing over the rock and o-rings. Apply the heat evenly, starting from one end and gradually moving towards the other end. Trim the upper portion of the tubing using a scalpel or scissors.

F) Invert this column and place small nipple of end platen into lower hole inside triaxial cell (make sure seals around o-rings remain intact).

WARNING: the top of the cell can move freely around the ram; hold it and make sure it does not move (i.e. fall) down prematurely.

G) Screw down top of cell, taking care to hold the ram so that it does not spin. Also make sure not to damage the o-ring near the top of the cell.

\section{A.4.3 Method to Put Hydraulic 011 into the Triaxial Cell}

A) Place triaxial cell in the load frame. (WARNING: hold the cell at the base or valve connections; do not hold on to the ram nor pull the ram or it will separate from the shrink tubing seal and the sample.)

B) Move the loading ram up to confine the triaxial cell in the load frame.

C) Inject oil into cell.

1) Connect air hose from the air supply to the upper fitting on the oil reservoir.

2) Connect oil line to central valve of oil reservoir and bottom lateral valve of triaxial cell.

3) Connect quick-release fitting to top lateral valve of cell.

4) Open tank valve and the lateral pressure (top and bottom) and bottom pore pressure valves of the triaxial cell.

5) Get beaker ready to catch oil as it comes out of top lateral valve.

6) When oil flows from the top lateral valve, shut the valve. Cell is now full and air pressure can be removed from the tank (close the tank valve first).

7) Disconnect oil line from cell.

8) Hook up pump to the same fitting (bottom latera1).

9) Install pressure gage to top lateral pressure valve. 
10) Release air pressure from tank SLOWLY.

A.4.4 Pressurize the Triaxial Cell and Test

A) Place the triaxial cell in the load frame. Make sure that the cell is in contact with the top and bottom loading platens.

B) Connect the wires to the strain indicator and switch-and-balance unit.

C) Apply an isotropic stress by increasing the confining pressure (using hand-pump) and axial pressure (Adisoma et al., 1988, pp. 81-84) simultaneously. Axial load should match confining pressure (approximately 3.5 lbs to $1 \mathrm{psi}$ for a 2 inch diameter sample).

D) Plane strain condition can be maintained by gradually increasing the confining pressure while the axial position is maintained constant. Axial stress is measured as a function of confining pressure.

E) Read the axial and lateral deformations (strains) of the borehole by means of the strain indicator. Read the strain to the nearest microstrain. Read the strains at every $10 \mathrm{MPa}$ stress increment. Record a minimum of three readings for each stress increment.

F) Increase the confining pressure to $60 \mathrm{MPa}$. Failure of the borehole (i.e. borehole breakouts) can be detected by a sudden change of the strain readings. Record the strains and stresses at failure.

G) If the borehole does not fail at the maximum confining pressure (60 MPa), unload and reload the sample (repeat steps $C$ through $F$ ).

H) Remove the sample from the triaxial cell and examine the borehole. Map the fractures around the borehole (breakout depth and angle, if there are any).

\section{A. 5 References}

Adisoma, G.S., R. Armstrong, K. Fuenkajorn, and J.J.K. Daemen, 1988, "Geomechanics Laboratory Manual," Department of Mining and Geological Engineering, University of Arizona, Tucson.

ASTM D2664-80, "Standard Test Method for Triaxial Compressive Strength of Intact Rock Core Specimens," Annual Book of ASTM Standards, Section 4, Construction, Vol. 04.08, Soil and Rock; Building Stones, American Society for Testing and Materials, Philadelphia. (Also standardized as ANSI/ASTM D2664-80)

ASTM D2938-79, "Standard Test Method for Unconfined Compressive Strength of Intact Rock Core Specimens," Annual Book of ASTM Standards, Section 4, Construction, Vol. 04.08, Soll and Rock; Building Stones, American Society for Testing and Materials, Philadelphia. (Also standardized as NSI/ASTM D2938-79) 
Measurements Group, Inc., 1983, "Student Manual for Strain Gage Technology," Bulletin 309, Measurement Group, Education Division, Raleigh, N.C.

Mordan, G.C., 1983, "Adhesives and Installation Techniques," Strain Gauge Technology, A.L. Window and G.S. Holister (eds.), Ch. 2, pp 39-83, Applied Science Publishers, England.

Vogler, U.W. and K. Kovari, 1977, "Suggested Methods for Determining The Strength of Rock Material in Triaxial Compression," International Society for Rock Mechanics, Commission on Standardization of Laboratory and Field Tests, Committee on Laboratory Tests, Document No. 7, March 1977. Published in International Journal of Rock Mechanics and Mining Sciences and Geomechanics Abstracts, Vo1. 15, no. 2, pp. 47-51, 1978. Also published in Rock Characterization Testing and Monitoring: ISRM Suggested Methods, E.T. Brown, ed. Published for the Commission on Testing Methods, International Society for Rock Mechanics by Pergamon Press, Oxford, 1981. 


\section{APPENDIX B \\ INSTALLATION PROCEDURE FOR \\ STRAIN GAGE INSIDE A BOREHOLE}

\section{B.1 Objective}

This procedure describes a method to install strain gages on a borehole wall. The procedure is applicable for hole sizes from 12.5 to $25.4 \mathrm{~mm}$ in diameter.

\section{B.2 Strain Gage Description}

Two types of electrical resistance strain gage rosettes manufactured by Measurements Group, Inc., have been selected for measuring strain. The polyaxial samples have CEA-06-125UT-120 gages. The triaxial samples have CEA-06-062UT-120 gages. CEA designates a fully encapsulated Constantan grid gage with a flexible polyamide backing and large copper soldering tabs for ease of soldering. The description 06 indicates the coefficient of thermal expansion to be $6 \mathrm{ppm} /{ }^{\circ} \mathrm{F}$. The gage arrangement UT describes a rosette of two side-by-side gages, one at $90^{\circ}$ to the other. The active gage length in thousandths of an inch is indicated as either 125 or 62 . The gage resistance is 120 ohms.

\section{B. 3 Procedure for Gage Installation}

(1) To remove any asperities, sand down the borehole with $\$ 280$ grit abrasive paper wrapped and taped around one end of a $3 / 8$ inch wood dowel. Blow out the rock dust and remove and clean with cottontipped applicators.

(2) Degrease the section of the borehole where the strain gages are to be applied with a trichloroethane based cleaner. (Chlorothene NU). Apply a weak acid solution (Conditioner A) and a weak base solution (Neutralizer 5) to further clean the rock surface. Apply the cleaners with cotton-tipped applicators, using a brushing motion directed away from the gage area.

(3) Apply a precoat to the gage area to fill in small pores in the rock surface. The precoat consists of a small amount (three to five drops) of M-Bond 200 strain gage adhesive and its catalyst, spread onto the gage area with cotton-tipped applicators. Repeat steps 1 and 2 to remove excess adhesive down to the rock surface. Clean the rock surface.

(4) Cut a rectangular piece of Mylar to $34 \mathrm{~mm}$ width and to a length approximately $50 \mathrm{~mm}$ greater than that of the sample. 
(5) Center the sample on the Mylar strip. Mark the positions of the ends of the sample. Draw a lateral centerline at the point midway between the two endmarks. Make two longitudinal centerline marks, each $6 \mathrm{~mm}$ from the midpoint of the lateral centerline. Use the lateral and the two longitudinal centerline marks to locate the two gage rosettes on the Mylar strip. Place the two rosettes $180^{\circ}$ apart from each other around the circumference of the borehole.

(6) Prepare leadwires from 22 gauge, nylon insulated, solid wire. Cut the wires to approximately $40 \mathrm{~cm}$ long. Strip the insulation $2 \mathrm{~mm}$ at one end of each wire. Tin the end. Six leadwires are needed for each rosette.

(7) Gently scrape the copper solder tabs of the strain rosettes with a scalpel to remove oxidization. Put a small "pillow" of solder on each solder tab. This facilitates the attachment of the leadwires.

(8) Use a three-wire system for the leadwires. Attach two leadwires together to one tab of a gage and one wire to the other tab. Using a gage (still in its holder) as a guide, position each leadwire with respect to the appropriate tab and secure it on a piece of adhesive tape. Tape the leadwires together at other points along their length to prevent their becoming tangled. Mark the leadwires at the other end to identify to which gage they go.

(9) Partially remove a gage rosette from its holder so that only the solder tabs are exposed. Tape the holder down to the work table. Place the leadwires in the proper position on top of the tabs. Solder the leadwires to the tabs. Remove any tape holding down wires or gages. Place the gage fully in its holder until needed.

(10) Apply a small amount (one or two drops) of $\mathrm{M}$-Bond 200 strain gage adhesive and catalyst to the non-bonding side of the two strain rosettes. Immediately glue the rosettes to the Mylar strip with the bonding side up. Also, secure the leadwires along the length of the strip. Tape a soft rubber square to the other side of the Mylar strip, opposite the rosette.

(11) Prepare a $10 \mathrm{~g}$ container of M-Bond AE-10 strain gage adhesive according to package instructions. Apply a small amount to the bonding side of the strain rosettes. Roll up the Mylar strip and insert into the sample borehole until the endmarks on the Mylar are aligned with the ends of the sample.

(12) Insert a $3 / 8$ inch O.D. Tygon tubing into the borehole, extending about $25 \mathrm{~mm}$ past both ends of the rolled up Mylar strip. Seal one end with clamps; connect the other end to a nitrogen cylinder. Apply a pressure of $.28 \mathrm{MPa}$ to the tubing. Allow the adhesive to set at room temperature $\left(20-24^{\circ} \mathrm{C}\right)$ for 6 to 24 hours. 
PROCEDURE FOR BIAXIAL BOREHOLE DEFORMATION AND STABILITY TESTS USING POLYAXIAL CELL

\section{c.1 Objective}

The purpose of this test procedure is to determine the deformation and stability of a borehole in a rock sample subjected to biaxial loading normal to the hole axis. The deformation and stability of the borehole are measured as a function of mean and differential stresses.

\section{C.2 Apparatus}

- polyaxial cell (Cobb and Daemen, 1982,1 pp. 28-31)

- flatjacks (4)

- Enerpac EH-80 hydraulic hand pumps (2)

- Enerpac JSL-1002 hydraulic load cell

- shut-off valves (3)

- loading platens (10 × $10 \times 5 \mathrm{~cm})$

- pressure gages (3)

- nitrogen gas tank

- regulating valve

- gas-over-oil pressure intensifier (Fuenkajorn and Daemen, 1986, pp. 257-260)

- strain gages (Micro-Measurement: WA-06-500WT-120)

- strain indicator with switch balance unit

- digital thermometer and thermocouple

\section{C.3 Sample Specifications}

The test specimen measures $100 \times 100 \times 200 \mathrm{~mm}$. Grind all surfaces flat and parallel. The perpendicularity and parallelism should be less than $0.5^{\circ}$. The block sample has a $25 \mathrm{~mm}$ diameter coaxial hole. Keep the eccentricity of the center hole as small as possible.

\section{C.4 Test Procedure}

Figure C.1 gives the laboratory arrangement for the biaxial borehole deformation and stability tests using a polyaxial cell. Install electrical resistance strain gages at the midsection of the borehole. Surface preparation and installation procedure are given in Appendix $B$. Load the sample into the polyaxial cell with a flatjack placed between

1 Cobb, S.I. and J.J.K. Daemen, 1982, "Polyaxial Testing of Borehole Plug Performance," Technical Report, Contract No. NRC-04-78-271, prepared for the U.S. Nuclear Regulatory Commission, Office of Nuclear Regulatory Research, SAFER Division, by the Department of Mining and Geological Engineering, University of Arizona, Tucson. 
the cell and sample surface. Connect the flatjacks across the hole diameter to a hydraulic hand pump via a pressure gage and a pressure shut-off valve.

Connect the strain gages to a switch balance unit and strain indicator. Apply the lateral stresses by pressurizing the flatjacks. The applied stresses are maintained constant during the deformation measurement by using the pressure shut-off valves. Read the circumferential and axial strains to the nearest microstrain. Read the oil pressure to the nearest $10 \mathrm{kPa}$. Make at least three strain measurements for each set of applied stresses. A new set of applied boundary stresses can be obtained by gradually changing (increasing or decreasing) the pressure in the flatjacks. The temperature of the testing room is maintained constant at $22 \pm 2^{\circ} \mathrm{C}$.

\section{5 Reference}

Fuenkajorn, K. and J.J.K. Daemen, 1986, "Experimental Assessment of Borehole Wall Drilling Damage in Basaltic Rocks," NUREG/CR-4641, Technical Report, prepared for U.S. Nuclear Regulatory Commission, Office of Nuclear Regulatory Research, Division of Radiation Programs and Earth Sciences, by Department of Mining and Geological Engineering, University of Arizona, Tucson. 


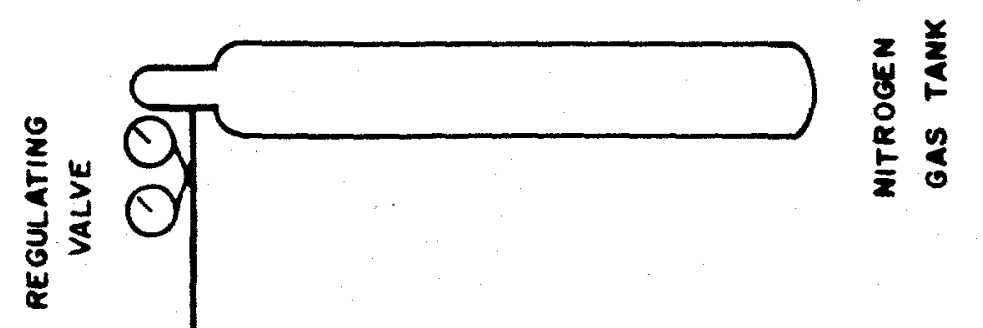

젱

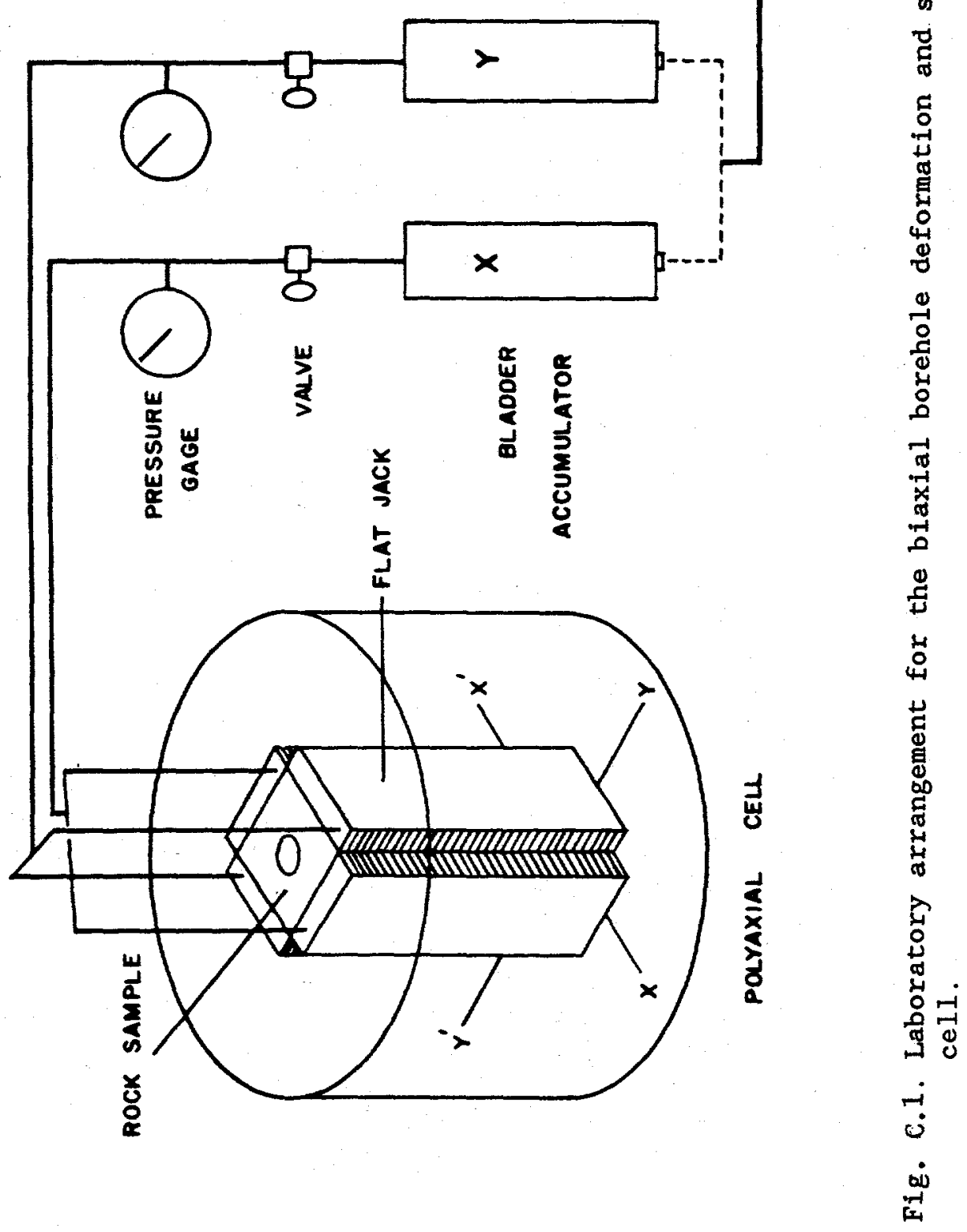




\section{APPENDIX D \\ PROCEDURE FOR BIAXIAL BORHEOLE STABILTTY TESTS \\ USING LATERAL LOAD FRAME}

\section{Objective}

The purpose of this test procedure is to determine the stresses that induce borehole breakouts and to map fracture patterns around the borehole in a rock block subjected to biaxial loading.

\section{D.2 Apparatus}

- load frame (SBEL CT-500)

- servocontroller (SBEL 447)

- lateral load frame (200 kN capacity) (Figure D.1)

- Enerpac hydraulic load cell and hand pump (optional; for higher lateral stress)

- shut-off valve

- pressure gage

- strain gages

- strain indicator(s) with switch and balance unit

- digital thermometer and thermocouple

- linear voltage displacement transducer (LVDT)

- displacement dial gage.

\section{3 Sample Specifications}

The test specimen measures $200 \times 200 \times 100 \mathrm{~mm}$ (nominal). Grind all surfaces flat and parallel. The perpendicularity and parallelism should be less than $0.5^{\circ}$. The block has a 20-30 mm diameter center hole. The hole is cored perpendicular to the sample major surfaces. Eccentricity of the center hole should be kept minimal. Map locations and orientations of petrographic features (vesicles, inclusions, flow layers, etc.) and of fractures or cracks. Detailed photographs of the block, and in particular of the areas around the hole, are made to allow post-test correlation between fracture patterns and local rock features, in particular inhomogeneities.

\section{4 Test Procedure}

The test is performed by applying lateral stress to the sample using a lateral load frame and hydraulic load cell or by tensioning bolts with a torque wrench. An electronic load cell is used to measure the lateral load. The vertical stress is applied by the SBEL (CT 500) load frame. Several options of loading sequences can be chosen, e.g. maintaining the lateral stress constant and increasing the vertical stress, or increasing the lateral and vertical stresses monotonically. The tangential and axial strains on the hole wall and tangential and radial strains around the borehole are measured using electrical resistance strain gages. 


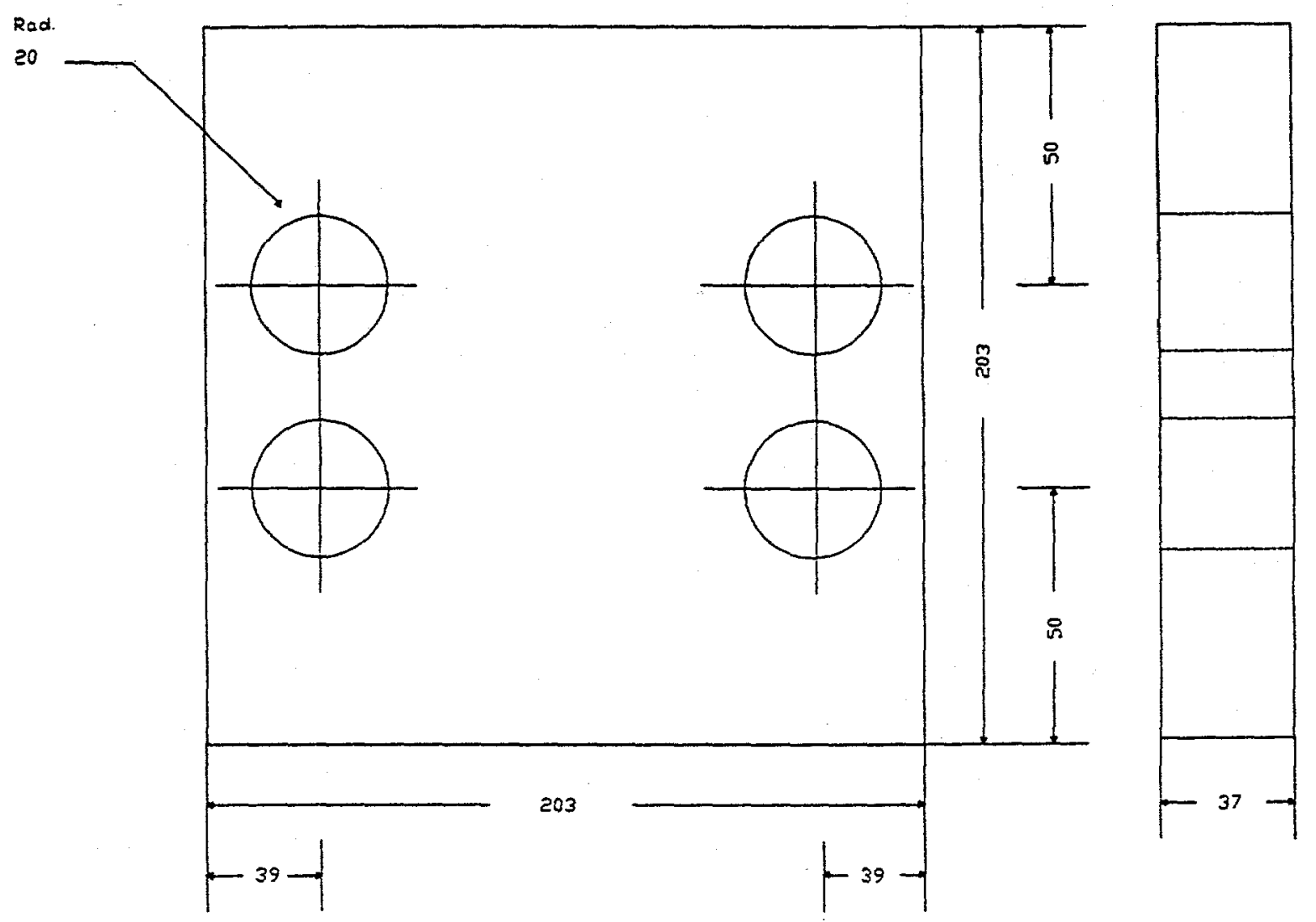

All dimensions in millimeters

All dimensions nominal

Figure D.1 Dimensions of load platen of lateral load frame. 
Fracture initiation and propagation are monitored visually and recorded photographically. Detailed fracture propagation maps are prepared to allow interpretation of the results in terms of local inhomogeneities and in terms of published analyses of failure patterns around boreholes.

Test procedure:

- Put the rock sample into the lateral frame. Tighten the four bolts to secure the steel platens.

- Install LVDT's between the two platens to measure lateral deformation of the rock.

- Place the sample and the lateral frame in the SBEL load frame.

- Several options of loading sequences can be followed. The lateral load is applied by pressurizing the load cell using a hydraulic hand pump. The vertical strain or load is applied by an SBEL (447) servocontroller.

- Calculate the lateral load from the oil pressure of the hydraulic load ce11, read by means of a pressure gage. Read the axial load from the gage of the SBEL load frame.

- Monitor and record the temperature of the testing room during the test.

- Increase the vertical load to $2.2 \times 10^{6} \mathrm{~N}$ (capacity of SBEL load frame).

- Record all strains, stresses, and time at failure.

- Map and sketch the fracture pattern at multiple loads and/or strains. 


\begin{tabular}{|c|c|}
\hline $\begin{array}{l}\text { U.S. NUCLEAR REGULATORY COMMISSION } \\
\text { BIBLIOGRAPHIC DATA SHEET } \\
\text { (See instructions on the reverse) }\end{array}$ & 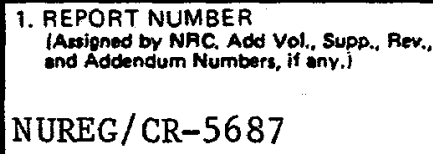 \\
\hline \multirow{4}{*}{$\begin{array}{l}\text { 2. TITLE AND SUBTITLE } \\
\text { Borehole Stability in Densely Welded Tuffs }\end{array}$} & \\
\hline & DATE REPORT PUBLISHED \\
\hline & \begin{tabular}{|c|c|} 
MONTH & YEAR \\
July & 1992
\end{tabular} \\
\hline & $\begin{array}{l}\text { 4. FIN OR GRANT NUMBER } \\
\text { L1476 }\end{array}$ \\
\hline \multirow{2}{*}{$\begin{array}{l}\text { 5. AUTHOR(S) } \\
\text { K. Fuenkajorn, J. J. K. Daemen }\end{array}$} & $\begin{array}{l}\text { 6. TYPE OF REPORT } \\
\text { Technical }\end{array}$ \\
\hline & $\begin{array}{l}\text { 7. PERIOD COVERED //nclusive Dares' } \\
1989-1991\end{array}$ \\
\hline
\end{tabular}

8. PERFOAMING ORGANIZATION - NAME AND ADDRESS IIf NRC, provide Division, Office or Region, U.S. Nuclear Regulazory Commission, and mailing address; if contractor, provide name ond maifing address.)

Department of Mining and Geological Engineering

University of Arizona

Tucson, AZ 85721

9. SPONSORING ORGANIZATION - NAME AND ADDRESS II NRC, ivpe "Same as above"; if contractor, provide NRC Division, Office or Region, U.S. Nuclear Regulatory Commission, and maiting address.)

Division of Regulatory Applications

Office of Nuclear Regulatory Research

U.S. Nuclear Regulatory Commission

Washington, DC 20555

10. SUPPLEMENTARY NOTES

11. ABSTRACT 1200 word or less 1 Failure of host rock at seal locations may allow bypass tlow around seals. This report presents an investigation of compressive failure around boreholes in densely welded Apache Leap tuff. Triaxial and polyaxial tests have been performed on cylinders and blocks containing coaxial cored holes. Test hole diameters are $14 \mathrm{~mm}$ for trlaxial testing and $25.4 \mathrm{~mm}$ for biaxial testing.

To induce breakouts requires stresses that exceed elastically calculated boundary stresses equal to the uniaxial compressive strength. Failure patterns are influenced by heterogeneity: soft inclusions fail first. Such failures remain localized. The stronger surrounding matrix maintains hole stability. An elastic analysis of hole stability in welded tuff may provide a significant safety margin. This conclusion needs to be qualified: all experiments have been conducted on small diameter boreholes.

It would be desirable to conduct borehole stability experiments on larger holes. of particular importance may be the influence of flow layers in tuff on borehole stability. Effects of flow layers have been minimized by preparing all samples normal to the flow layers. Also desirable would be an investigation of the influence of environmental conditions, especially temperature and moisture content, and of the strength under sustained long-term loading. A more comprehensive analysis of the results should be performed, including evaluation of recent theoretical models for borehole breakouts.

12. KEY WORDS/DESCR!PTORS /List words or phrases that will assist researchers in focaring the repont.

rock strength

rock failure

borehole failure

borehole collapse

borehole breakouts

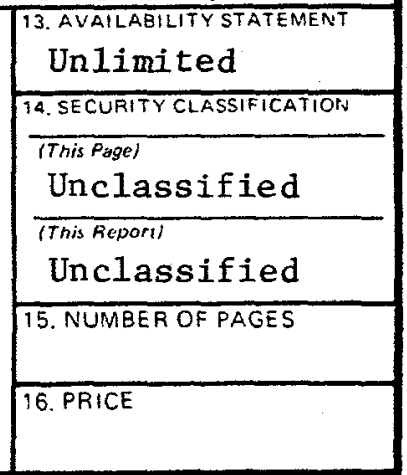

